\title{
October 1999 Groundwater Sampling and Data Analysis, Distler Brickyard Site, Hardin County, Kentucky
}

\author{
Jennifer P. Martin ${ }^{1}$ \\ Lance N. Peterson ${ }^{1}$ \\ Charles J. Taylor ${ }^{2}$
}

Published March 2000

1. Bechtel BWXT Idaho, Idaho Falls, Idaho

2. U.S. Geological Survey, Water Resources Division, Louisville, Kentucky

Idaho National Engineering and Environmental Laboratory

Environmental Remediation Technologies Department Idaho Falls, Idaho 83415

\section{Prepared for the}

U.S. EPA National Exposure Laboratory, Technology Support Center, Characterization and Monitoring Branch and for the

U.S. Department of Energy

Assistant Secretary for Environmental Management

Under DOE Idaho Operations Office

Contract DE-AC07-99ID13727 



\section{DISCLAIMER}

This report was prepared as an account of work sponsored by an agency of the United States Government. Neither the United States Government nor any agency thereof, nor any of their employees, make any warranty, express or implied, or assumes any legal liability or responsibility for the accuracy, completeness, or usefulness of any information, apparatus, product, or process disciosed, or represents that its use would not infringe privately owned rights. Reference herein to any specific commercial product, process, or service by trade name, trademark, manufacturer, or otherwise does not necessarily constitute or imply its endorsement, recommendation, or favoring by the United States Government or any agency thereof. The views and opinions of authors expressed herein do not necessarily state or reflect those of the United States Government or any agency thereof. 


\section{DISCLAIMER}

Portions of this document may be illegible in electronic image products. Images are produced from the best available original document. 
INEEL/EXT-2000-00198

Revision 0

March 2000

\section{October 1999 Groundwater Sampling and Data Analysis, Distler Brickyard Site, Hardin County Kentucky}

Approved by:

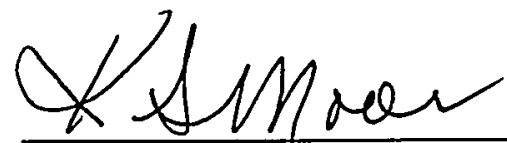

Kenneth S. Moor, Program Manager

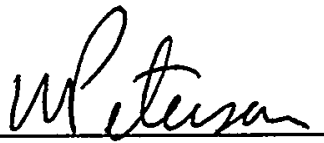

Lance N. Peterson, Project Manager

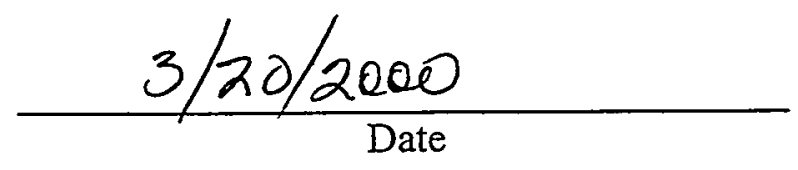

$\frac{3 / 20 / 00}{\text { Date }}$ 



\section{ABSTRACT}

This report describes the results of a sampling event conducted at the Distler Brickyard Superfund Site, Hardin County, Kentucky, October 1999. The purpose of the sampling event was to evaluate the extent of natural biodegradation of chlorinated aliphatic hydrocarbons (CAH) occurring at the Site. Sampling locations were selected to evaluate three areas of the suspected $\mathrm{CAH}$ plume: the source area, an axial cross-section, and a downgradient transect. Due to inadequate recharge to and the poor physical condition of some monitoring wells at the Site, the sampling approach was modified to reflect wells that could be sampled.

Results indicate that natural anaerobic degradation of chlorinated aliphatic hydrocarbons is occurring in the presumed source area around monitoring well GW-11. The primary contaminant of concern, trichloroethene, migrates downgradient from the source area into the Coarse Grained Alluvium Aquifer at concentrations slightly greater than the Maximum Contaminant Level (MCL). Based on the data available, the following hypothesis is proposed: the source area has been remediated through soil removal activities and subsequent anaerobic reductive dechlorination. If this is the case, this Site may be a good candidate for implementation of a monitored natural attenuation remedy. However, more data are necessary before this hypothesis can be confirmed.

Additional sampling is required to address data gaps before final recommendations for a remedial remedy can be made. These data gaps include: evaluating the effect of seasonal variations on contaminant concentrations, determining the conditions and status of the source area in the Fine Grained Alluvium, determining conditions along the eastern edge of the flowpath from the source area (GW-11 $\rightarrow$ MW-3), and evaluating the extent of possible downgradient aerobic degradation of dechlorination products downgradient. The following activities are recommended to address these data gaps: 1 . Monitoring well reconnaissance, 2. On-site monitoring well installation, 3. Groundwater sampling, 4 . Soil gas sampling, and if necessary, 5 . Off-site monitoring well installation. Data collected through these activities will be used to evaluate the above hypothesis and to select the appropriate remedial remedy for this Site. 


\section{CONTENTS}

ABSTRACT

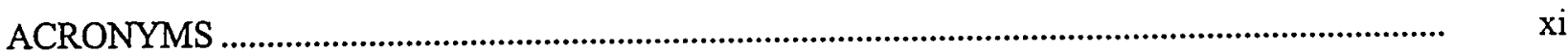

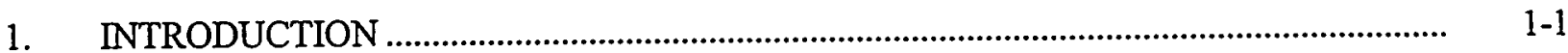

2. GOALS FOR SAMPLING EVENT .............................................................................

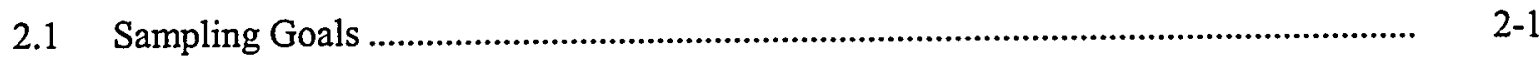

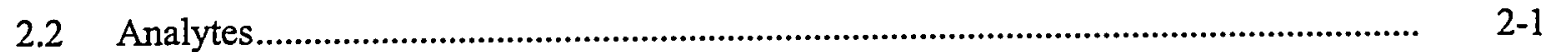

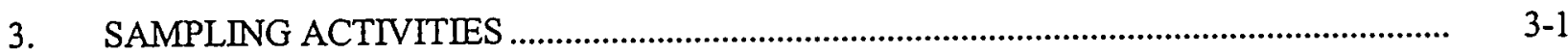

3.1 Sampling Locations ..........................................................................................

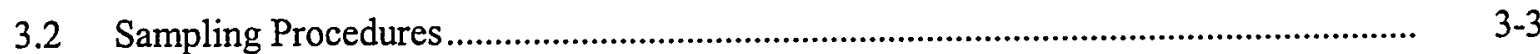

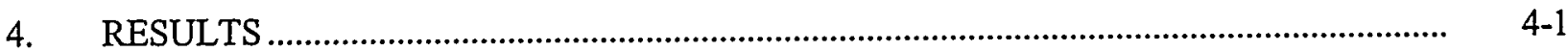

4.1 Electron Donor and Nutrient Concentrations ......................................................

4.2 Biological Activity Indicators .........................................................................

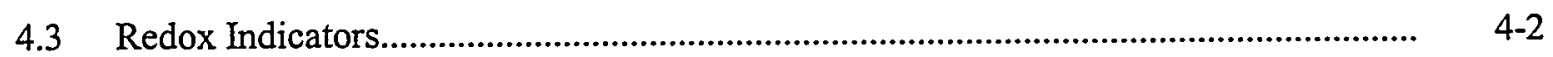

4.4 Chloroethene and Chloroethane Concentrations .......................................................... $4-3$

$4.5 \quad$ Water Quality Indicators ....................................................................................... $4-5$

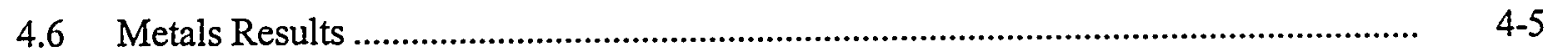

$4.7 \quad$ 1,4-Dioxane Concentrations .................................................................................. $4-5$

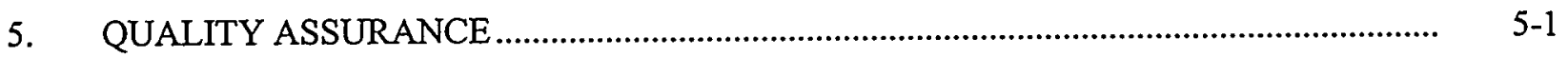

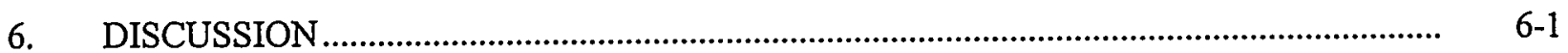

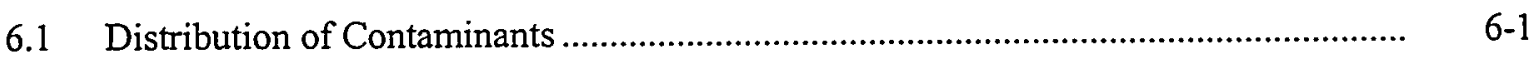

6.2 Anaerobic Reductive Dechlorination in the FGA ..................................................

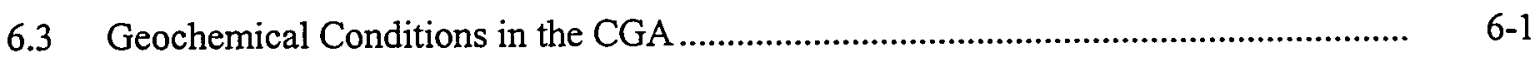

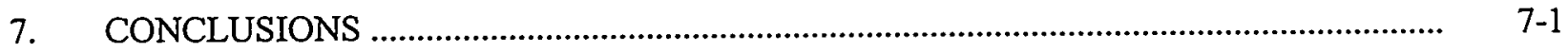

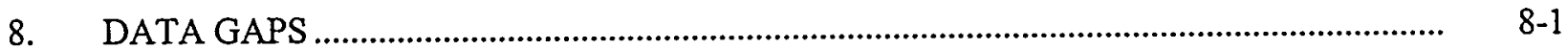

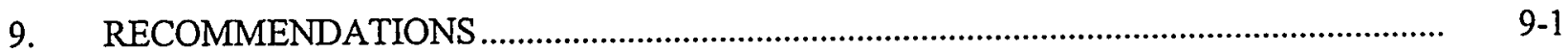


9.1 Additional Field Activities ........................................................................................

9.2 Remedial Activities ................................................................................................. $9-4$

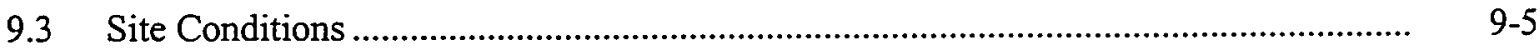

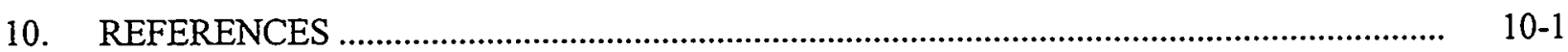

Appendix A-Volatile Organic Analysis Results - Total and Dissolved Metals Results

\section{FIGURES}

1-1. Distler Brickyard Site map.

3-1. Attempted and completed sampling locations, October 1999.

4-1. Redox conditions.

4-2. TCE and 1,1,1-TCA concentrations.

4-3. Biodegradation product cis-1,2-DCE

4-4. Abiotic degradation products trans-DCE and 1,2-DCA.

4-5. Advanced degradation products chloroethane and ethene.

4-6. Dechlorination product chloride.

9-1. Site map showing monitoring wells to be evaluated for future sampling and generalized locations for proposed additional monitoring wells.

\section{TABLES}

2-1. Analytes for evaluating the existence of ARD.

3-1. Attempted and completed sampling locations.

4-1. Electron donor concentrations ( $\mathrm{mg} / \mathrm{L}$ )

4-2. Biological nutrient concentrations ( $\mathrm{mg} / \mathrm{L})$

4-3. Biological activity indicator results $(\mathrm{mg} / \mathrm{L})$.

4-4. Redox indicator results. Data are in $\mathrm{mg} / \mathrm{L}$ unless otherwise noted.

4-5. Results of chloroethene and chloroethane $(\mu \mathrm{g} / \mathrm{L})$ and chloride $(\mathrm{mg} / \mathrm{L})$ analyses.

4-6. Water quality parameters.

4-7. Concentrations of 1,4-dioxane $(\mu \mathrm{g} / \mathrm{L})$. 


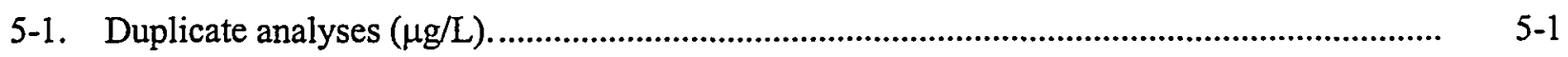

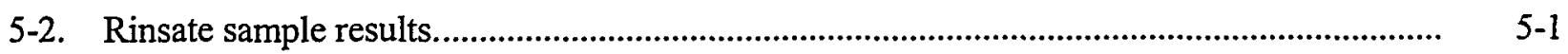

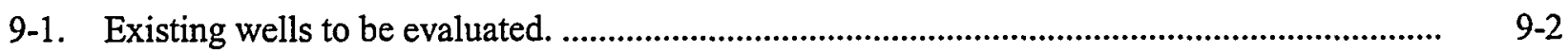




\section{ACRONYMS}

\begin{tabular}{|c|c|}
\hline ARD & anaerobic reductive dechlorination \\
\hline $\mathrm{CA}$ & chloroethane \\
\hline $\mathrm{CAH}$ & chlorinated aliphatic hydrocarbon \\
\hline CGA & Coarse Grained Alluvium \\
\hline COD & chemical oxygen demand \\
\hline $\mathrm{DCA}$ & dichloroethane \\
\hline DCE & dichloroethene \\
\hline DOC & dissolved organic carbon \\
\hline $\mathrm{EPA}$ & U.S. Environmental Protection Agency \\
\hline FGA & Fine Grained Alluvium \\
\hline KNREPC & $\begin{array}{l}\text { Kentucky Natural Resources and Environmental Protection } \\
\text { Cabinet }\end{array}$ \\
\hline MAH & monocyclic aromatic hydrocarbon \\
\hline MCL & maximum contaminant level \\
\hline MNA & monitored natural attenuation \\
\hline NAWQA & National Water-Quality Assessment Program \\
\hline ORP & Oxidation Reduction Potential \\
\hline PCE & tetrachloroethene \\
\hline $\mathrm{RA}$ & remedial action \\
\hline TCA & trichloroethane \\
\hline TCE & trichloroethene \\
\hline TeCA & tetrachloroethane \\
\hline USGS & U.S. Geological Survey \\
\hline VC & vinyl chloride \\
\hline VOC & volatile organic compound \\
\hline
\end{tabular}




\section{October 1999 Groundwater Sampling and Data Analysis, Distler Brickyard Site, Hardin County, Kentucky}

\section{INTRODUCTION}

The Distler Brickyard Site is located on unconsolidated alluvial and glacial outwash deposits along the Ohio River in northern Hardin County, Kentucky. The alluvium consists of two hydrostratigraphic units: the upper Fine Grained Alluvium (FGA) and the underlying Coarse Grained Alluvium (CGA). The FGA is approximately $12-\mathrm{m}(40-\mathrm{ft})$ thick and consists of silty clays with sand and peat lenses. The CGA is composed of coarse sand and gravel and is present in the western portion of the Site. Where present, it ranges from 0.4- to 6-m (1.5- to 20-ft) thick (de la Pena 1989, Duffey et al. 1983). The FGA/CGA are underlain by silt and limestone bedrock at a depth of 12- to $18-\mathrm{m}$ (40- to-60 ft) below ground surface.

The 28-ha (70-acre) site is a former brick manufacturing plant that was used as a waste recycling and storage facility between 1976 and 1979. During waste storage and recycling activities, drums of waste were stored aboveground. For this reason, the sources of contamination at the Site were drums spilling or leaking onto the soil surface and subsequently infiltrating to the water table (approximately 25 to $30 \mathrm{ft}$ ). Groundwater sampling during 1983 through 1985 indicated that groundwater in the vicinity of Monitoring Well GW-11 was the most highly contaminated at the Site. Analysis of data collected through 1985 identified a contaminant plume with the source area located near GW-11 (Anderson and Bomberger 1986) (Figure 1-1). The contaminants of concern included chlorinated aliphatic hydrocarbons (CAHs) (trichloroethene [TCE] and 1,1,1-trichloroethane [1,1,1-TCA] and degradation products), monocyclic aromatic hydrocarbons (MAHs) (i.e., petroleum hydrocarbons), and ketones.

The U.S. Environmental Protection Agency (EPA) published a Record of Decision in 1986 specifying the following remedial action (RA) activities (EPA 1998):

- Excavation of contaminated soil

- Extraction and treatment of contaminated groundwater

- Operation and maintenance of a groundwater treatment system.

Excavation of $382 \mathrm{~m}^{3}\left(500 \mathrm{yd}^{3}\right)$ of contaminated soil from the GW-11 area was completed in October 1988, and construction of the groundwater treatment system began in 1989 (OHM 1990). There is no documentation of soil removal from the area around GW-4, another potential source area. Analysis of data collected during operations of the groundwater treatment system indicated that most of the contaminants were located in the FGA, which because of its relatively low hydraulic conductivity $\left(10^{-8}\right.$ to $10^{-4} \mathrm{~cm} / \mathrm{s}$ ), exhibits low flow rates (EPA 1998). Due to the low hydraulic conductivity in the FGA, advective transport of contaminants through the FGA to the CGA is slow. Thus, removal of contaminants by groundwater extraction and treatment is not an effective remediation method for this system. 
Previous investigations (Anderson and Bomberger 1986, U.S. Geological Survey [USGS] in preparation) revealed evidence that suggested biodegradation (via anaerobic reductive dechlorination [ARD]) of CAHs was occurring in the FGA. The evidence for ARD of CAHs in the FGA includes:

- The absence of TCE and tetrachloroethene (PCE), and the decrease in concentrations of $1,1,1-\mathrm{TCA}$ in the FGA

- The presence of the degradation product chloroethane (CA) in the FGA

- The widespread occurrence of the intermediate degradation products dichloroethene (DCE) and dichloroethane (DCA) in both the FGA and CGA

- The predominance of cis-1,2-DCE and 1,1-DCA, the biologically-favored degradation products, over trans-1,2-DCE and 1,1-DCE (Vogel et al., 1987; Barbee 1994, USGS in preparation).

These investigations also indicated that conditions in the CGA were less favorable for ARD. The groundwater in the CGA may be oxygenated due to recharge from the Ohio River and electron donors necessary for ARD may be absent. This interpretation was supported by the presence of primary contaminants PCE, TCE, and 1,1,1-TCA in the CGA and the absence of the degradation product chloroethane. The absence of petroleum hydrocarbons also suggested oxidizing conditions (USGS in preparation). 


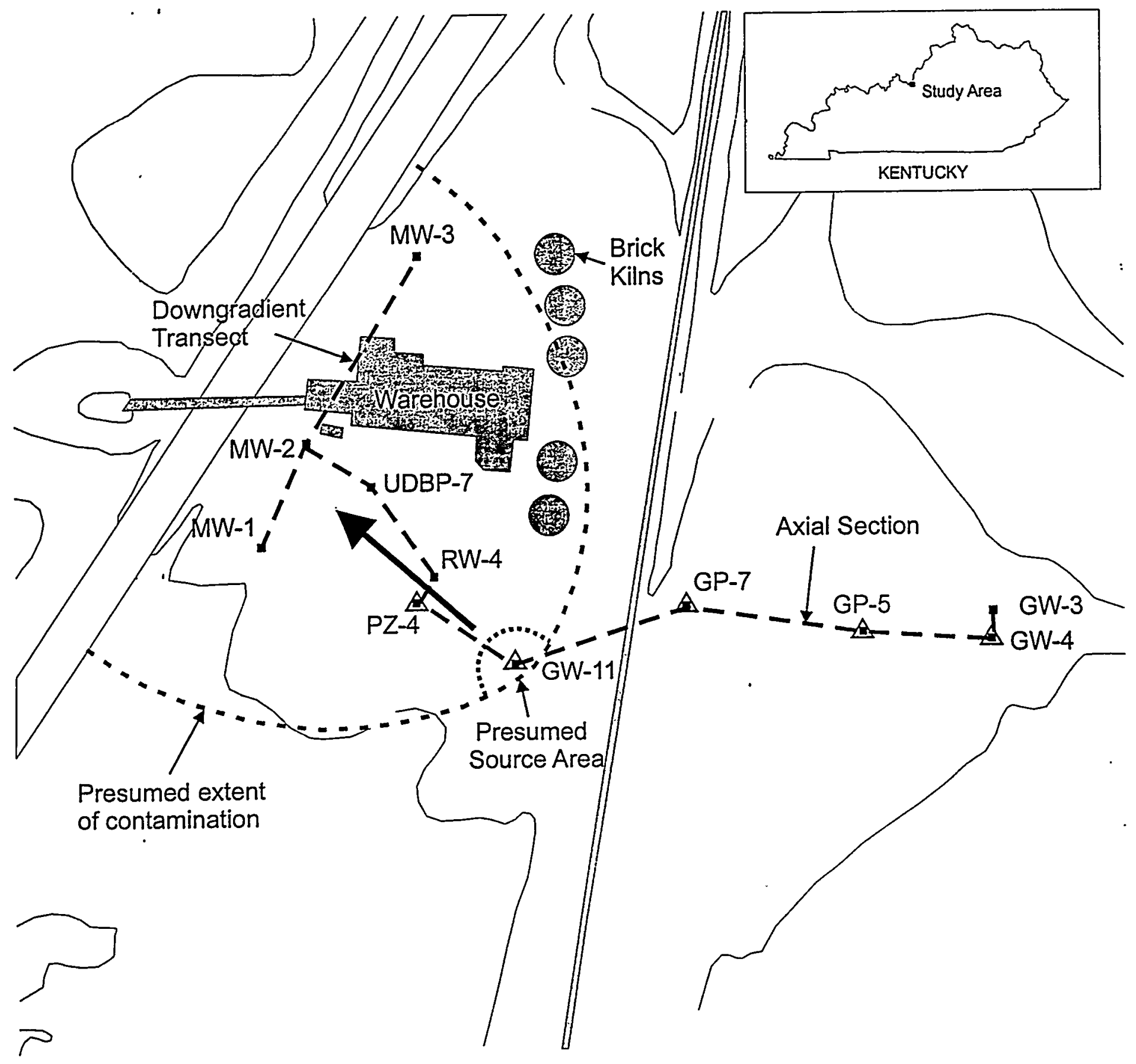

\section{EXPLANATION}

\section{$\triangle \quad$ FGA Well \\ - cGaWell}

GW-1 Well identifier

$\rightarrow$ Presumed Groundwater Flow Direction

Figure 1-1. Distler Brickyard Site map showing locations to be sampled during the October 1999 sampling event, the presumed extent of contamination, presumed source area location, and presumed groundwater flow direction (large arrow). 


\section{GOALS FOR SAMPLING EVENT \\ 2.1 Sampling Goals}

The goal of this sampling event was to determine the extent to which natural biodegradation of chlorinated aliphatic compounds may be occurring at the Site. The field sampling plan (Martin et al. 1999) outlined the locations selected for sampling and the rationale for the selection of these locations. Sampling locations were divided into three groups (Figure 1-1):

- Locations in the FGA, including possible source areas: GW-4, GW-11, GP-5, and GP-7

- Axial cross-section through the plume and suspected source area (includes both FGA and CGA locations): GW-3, GW-4, GP-5, GP-7, GW-11, RW-4, PZ-4, UDBP-7, MW-2

- Downgradient transect (all CGA): MW-1, MW-2, MW-3. 1999.

Groundwater sampling was conducted at the Distler Brickyard Site during October 18 through 28,

\subsection{Analytes}

The suite of analytes necessary for evaluating the existence of ARD is described in detail in Section 2.5 of the field sampling plan (Martin et al. 1999). A summary of the parameters is presented in Table 2-1.

Table 2-1. Analytes for evaluating the existence of ARD.

Parameters

Dechlorination Indicators

Electron Donor Indicators

Oxidation-Reduction Indicators

Biological Nutrients
Chlorinated Ethenes and Ethanes

Ethene and Ethane

Chloride

Chemical Oxygen Demand

Dissolved Organic Carbon

Dissolved Oxygen

Ferrous Iron

Nitrite, Nitrate/Nitrite, Sulfate, Methane

Oxidation Reduction Potential (ORP)

Phosphate and Ammonia (as N) 
Table 2-1. (continued).

\section{Parameters}

Water Quality Indicators

Temperature

$\mathrm{pH}$

Specific Conductance

Biological Activity Indicators

Carbon Dioxide

Alkalinity

Aquifer Geochemistry

Major Cations (calcium, magnesium,

potassium, aluminum, and sodium)

Conservative Tracer

1,4-dioxane 


\section{SAMPLING ACTIVITIES}

\subsection{Sampling Locations}

Reconnaissance of the Site at the start of sampling activities revealed a number of wells that were unfit for sampling. Because some wells could not be sampled, additional wells that were not part of the original field sampling plan were evaluated and included in the sampling program. The wells were divided into four groups that were used to meet the original goals of the sampling event: source area and FGA geochemical conditions, axial cross-section and downgradient transect. An off-site downgradient monitoring location was also added. Table 3-1 summarizes the sampling locations, indicating the wells that could be.sampled and those that were evaluated but not sampled. The well locations are presented in Figure 3-1.

Table 3-1. Attempted and completed sampling locations.

\begin{tabular}{|c|c|c|c|}
\hline Well & $\begin{array}{c}\text { Aquifer } \\
\text { Designation }\end{array}$ & $\begin{array}{l}\text { Sample } \\
\text { Collected? }\end{array}$ & Comment \\
\hline \multicolumn{4}{|l|}{ Source Area } \\
\hline GW-11 & FGA & Yes & \\
\hline GW-4 & FGA & No & $\begin{array}{l}\text { Uncapped well; bailed dry with insufficient recovery to } \\
\text { sample; very turbid water with black particulates and hair } \\
\text { (fur) }\end{array}$ \\
\hline GP-5 & FGA & No & Well could not be located \\
\hline GP-7 & FGA & No & Well could not be located \\
\hline \multicolumn{4}{|c|}{ Axial Cross-Section } \\
\hline GW-11 & FGA & Yes & \\
\hline UDBP-7 & CGA & Yes & \\
\hline UDBP-8* & CGA & Yes & $\begin{array}{l}\text { Well added to replace PZ-4; downgradient of source at } \\
\text { GW-11 }\end{array}$ \\
\hline MW-2 & CGA & Yes & \\
\hline GW-3 & CGA & No & $\begin{array}{l}\text { Uncapped well; bailed dry with no recovery indicating a } \\
\text { clogged screen; very turbid water with black particulates }\end{array}$ \\
\hline $\mathrm{PZ}-4$ & Transitional & No & Insufficient water to purge or sample \\
\hline RW-4 & CGA & No & Piping for groundwater extraction system prevented access \\
\hline \multicolumn{4}{|c|}{ Downgradient Transect } \\
\hline MW-1 & CGA & Yes & \\
\hline MW-2 & CGA & Yes & \\
\hline MW-3 & CGA & Yes & \\
\hline UDBP-4* & CGA & Yes & Well located along transect \\
\hline \multicolumn{4}{|c|}{ Off-Site Downgradient Monitoring Point } \\
\hline UDBW-3* & CGA & Yes & $\begin{array}{l}\text { Well location unknown at time FSP was prepared; added to } \\
\text { determine the extent of downgradient contaminant migration } \\
\text { in the CGA }\end{array}$ \\
\hline
\end{tabular}




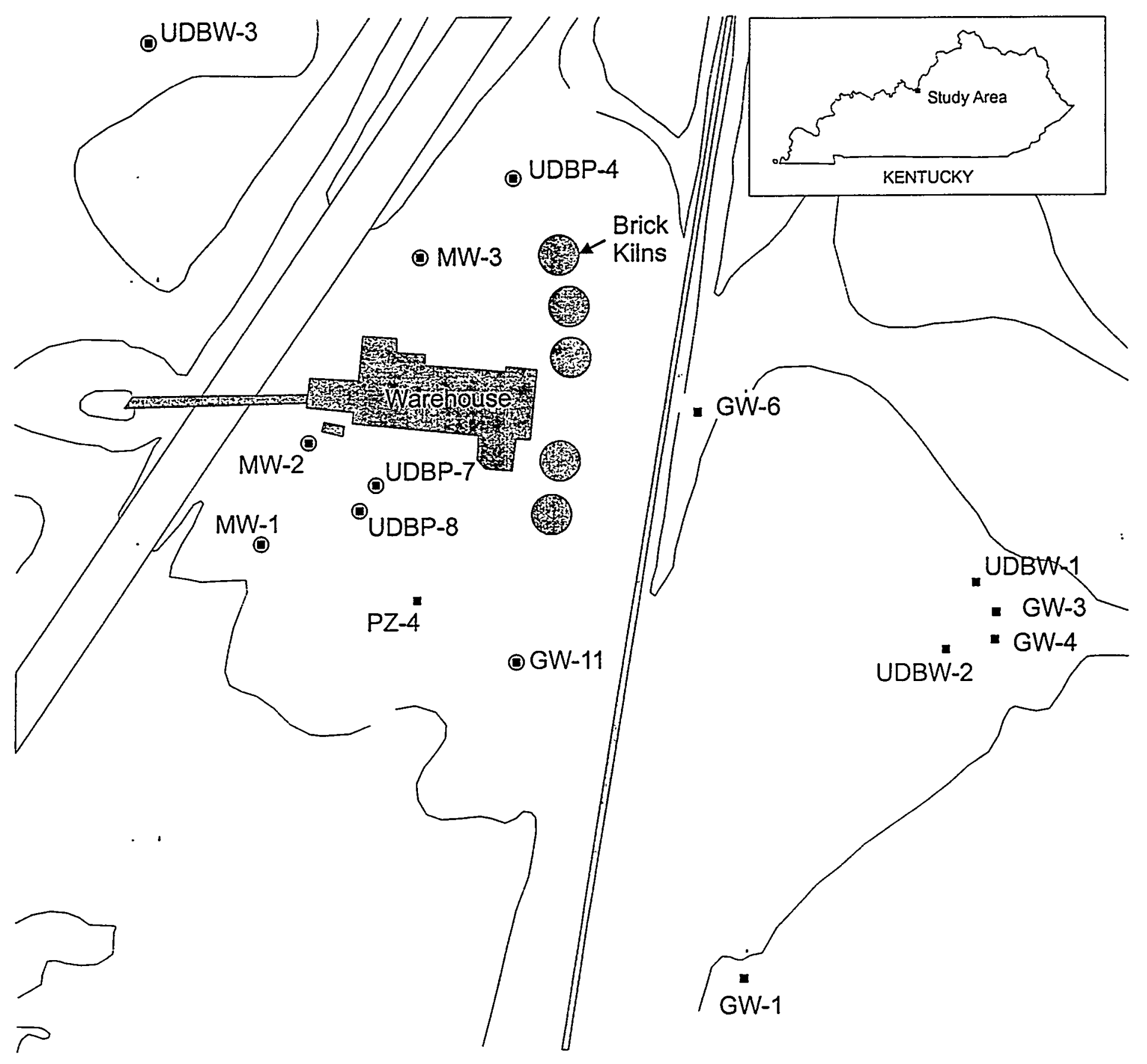

\section{EXPLANATION}

(-) Sampled Well

- Evaluated - Not Sampled

GW-1 Well identifier

Figure 3-1. Attempted and completed sampling locations, October 1999. 


\subsection{Sampling Procedures}

Sampling was conducted by the USGS Water Resources Division Kentucky District in accordance with the National Water-Quality Assessment Program (NAWQA) Ground-Water Data-Collection Protocols and Procedures (Koterba et al., 1995). Groundwater samples were collected with a Grundfos Rediflo2 submersible pump fitted with Teflon tubing. Wells were purged at 3.8 to $5.7 \mathrm{~L} / \mathrm{min}$ (1 to $1.5 \mathrm{gal} / \mathrm{min}$ ) until field water quality parameters (specific conductance, $\mathrm{pH}$, temperature, and dissolved oxygen) stabilized or the difference between successive measurements was less than $10 \%$. Field water quality parameters were monitored with a Hydrolab DataSonde 4 equipped with a flow-through cell. Purge water was discharged to the ground surface per agreement with Rick Hogan at the Kentucky Natural Resources and Environmental Protection Cabinet (KNREPC).

Carbon dioxide, ferrous iron, nitrite, and alkalinity measurements were performed in the field immediately upon sample collection in order to obtain representative results. Samples for these analyses were collected directly from the discharge tubing into the analysis vessel and analyzed immediately. This method ensured a fresh aliquot of sample for each analysis. The remaining analyses were performed at either the EPA Water Quality Laboratory (Athens, GA) or an EPA Contract Laboratory.

Decontamination of the pump and Teflon tubing was performed as the pump was removed from the well, approximately $3 \mathrm{~m}(10 \mathrm{ft})$ at a time. The following procedure was used: (1) Scrub with Liquinox (phosphate-free) soap and water, (2) Rinse with high pressure hot water sprayer, and (3) Rinse with deionized water. The pump exterior was cleaned in the same manner. The interior of the tubing was cleaned by pumping three tubing volumes of each in the following order: Liquinox soapy water, tap water, and deionized water. The entire decontamination process took approximately 1-hour per well. All decontamination water was discharged to the surface as described above. 


\section{RESULTS}

This section describes the results of the October 1999 sampling event. Results fall into the following categories: electron donor and nutrients, bioactivity indicators, redox parameters, chloroethene and chloroethane concentrations, water quality parameters, metals, and 1,4-dioxane concentrations.

Identification of $\mathrm{ARD}$ as a significant process relies on the integration of the results of each of the parameters presented in Table 2-1. In general, ARD of CAHs requires the appropriate microbial community and a sufficient supply of electron donor (and possibly nutrients). The remaining parameters (Table 2-1) will be affected by the ARD process as described in Section 2.5 of the field sampling plan (Martin et al., 1999). If ARD is occurring, the biological activity indicators carbon dioxide and alkalinity will be elevated. The electron donor supply will be adequate to meet the demands of competing electron acceptors (dissolved oxygen, nitrate, ferric iron, sulfate, and carbon dioxide), resulting in stronglyreducing conditions (sulfate-reducing to methanogenic). The appropriate redox conditions are indicated by the absence of electron acceptors and by the presence of methane. The strongest evidence for $A R D$ is the presence of advanced degradation products, cis-1,2-DCE, 1,1-DCA, CA, VC, ethene, and ethane. The remaining parameters are used to complete the understanding of the geochemical conditions and processes occurring at the Site. Below is a description of the results and the implications for assessing degradation processes at this Site.

\subsection{Electron Donor and Nutrient Concentrations}

In order for ARD to proceed, a sufficient supply of electron donor is required. Electron donor concentrations were measured using chemical oxygen demand (COD) and dissolved organic carbon (DOC). Concentrations of non-chlorinated organic compounds were also measured in volatile organic compound (VOC) samples (Appendix A). Both COD and DOC were relatively low at all monitoring locations ( $<10$ and $<20 \mathrm{mg} / \mathrm{L}$, respectively), with the highest concentrations being at GW-11 (53 and $32 \mathrm{mg} / \mathrm{L}$, respectively) and UDBW-3 (29 and $17 \mathrm{mg} / \mathrm{L}$, respectively) (Table 4-1). Non-chlorinated hydrocarbons were also detected in GW-11 at very low concentrations (Appendix A). These compounds were not detected at any other location with the exceptions of very low concentrations of 1 -methylnaphthalene (UDBP-7), benzo(c)thiophene (UDBP-7 and MW-1), and Freon 113 (UDBW-3). Complete results of VOC analyses are presented in Appendix A.

Nutrients required for biological growth include ammonia (as nitrogen) and phosphorus. Concentrations of both nutrients were lowest in UDBP-8 and UDBP-7, but were relatively low among all monitoring locations (Table 4-2).

The relatively low electron donor concentrations indicate that ARD processes may be electron donor limited. However, the FGA contains natural organic carbon in the form of peat deposits that may be providing an additional electron donor source that was not quantified by the COD and DOC measurements.

\subsection{Biological Activity Indicators}

The biological activity indicators are alkalinity and carbon dioxide (Table 4-3). Carbon dioxide is produced as a result of mineralization during ARD and of bio-oxidation of organics (denitrification, sulfate reduction, and fermentation) (Drever 1988). Alkalinity is another measure of carbon dioxide concentrations. For these reasons, ARD processes will result in an increase in carbon dioxide and alkalinity concentrations. 
Table 4-1. Electron donor concentrations (mg/L).

\begin{tabular}{|c|c|c|c|c|c|c|c|c|}
\hline Analyte & GW-11 & UDBP-8 & UDBP-7 & MW-3 & MW-1 & MW-2 & UDBP-4 & UDBW-3 \\
\hline $\begin{array}{l}\text { Chemical Oxygen } \\
\text { Demand }\end{array}$ & $53 \mathrm{~A}$ & $\mathrm{ND}$ & $\mathrm{ND}$ & $\mathrm{ND}$ & $\mathrm{ND}$ & 6.9 & $\mathrm{ND}$ & 29 \\
\hline $\begin{array}{l}\text { Dissolved Organic } \\
\text { Carbon }\end{array}$ & 32 & 18 & 17 & 16 & 17 & 8.1 & 8 & $17 \mathrm{~A}$ \\
\hline $\begin{array}{l}\mathrm{ND}=\text { not detected } \\
\mathrm{A}=\text { average value }\end{array}$ & & & & & & & & \\
\hline
\end{tabular}

Table 4-2. Biological nutrient concentrations (mg/L).

\begin{tabular}{lcccccccc}
\hline \multicolumn{1}{c}{ Analyte } & GW-11 & UDBP-8 & UDBP-7 & MW-3 & MW-1 & MW-2 & UDBP-4 UDBW-3 \\
\hline Ammonia (as N) & $0.2 \mathrm{~A}$ & 0.05 & 0.056 & ND & ND & 0.08 & 0.1 & 0.1 \\
Phosphorus (total P) & $0.17 \mathrm{~A}$ & 0.063 & 0.026 & 0.094 & $0.026 \mathrm{~A}$ & 0.54 & 0.13 & 0.42 \\
\cline { 1 - 2 } ND= not detected & A = average value & & & & & & \\
\hline
\end{tabular}

Table 4-3. Biological activity indicator results $(\mathrm{mg} / \mathrm{L})$.

\begin{tabular}{lccccccccc}
\hline \multicolumn{1}{c}{ Analyte } & GW-11 & UDBP-8 & UDBP-7 & MW-3 & MW-1 & MW-2 & UDBP-4 & UDBW-3 \\
\hline Alkalinity & 427 & 429 & 428 & 406 & 362 & 357 & 357 & 397 \\
Bicarbonate & 522 & 524 & 522 & 496 & 442 & 436 & 436 & 484 \\
Carbon Dioxide & 159 & 180 & 179 & 164 & 74 & 124 & 167 & 146 \\
\hline
\end{tabular}

The alkalinity and bicarbonate (calculated from the alkalinity) concentrations are slightly higher at GW-1 1, UDBP-8, and UDBP-7 than the remaining wells. Carbon dioxide concentrations are highest at UDBP-8 and UDBP-7. The low result at MW-1 is probably a result of operator error. The analysis was performed for the first time at the MW-1 location, and the titration may have been incomplete resulting in the relatively low value compared to the remaining wells. Also, the carbon dioxide measurement at GW-11 was probably affected by the method used to sample this well. Due to the extremely dry conditions during sampling, GW-11 was pumped dry, allowed to recharge, and then sampled. Carbon dioxide could have been lost to the atmosphere during the length of time required for the well to recharge prior to sample collection.

The slight elevation in alkalinity (and bicarbonate) observed in GW-11, UDBP-7, and UDBP-8 could be due to the presence of ARD processes occurring at this location. Background alkalinity and carbon dioxide concentrations are relatively high due to the carbonate bedrock at this Site. For this reason, expected increases due to ARD processes would be relatively small compared to the background levels.

\subsection{Redox Indicators}

In order for ARD of TCE and 1,1,1-TCA to be energetically favorable, competing electron acceptors must be absent, resulting in strongly-reducing conditions. Concentrations of the competing electron acceptors dissolved oxygen, nitrate, ferrous iron (reduced product) and sulfate were determined directly. Additionally, the presence of methane indicates strongly-reducing conditions. ORP was also used as an additional measure of redox conditions. The results are presented in Table 4-4. Dissolved oxygen concentrations ranged from $<1 \mathrm{mg} / \mathrm{L}$ at UDBP-7 and UDBP- 8 to $>5 \mathrm{mg} / \mathrm{L}$ at MW- 1 and MW-2. 
Nitrate concentrations were to be determined as the difference between a nitrite field test kit and a laboratory analysis of total nitrate-nitrite. The nitrite field test kit lacked the precision and a low enough detection limit to quantify the low levels of nitrite in the groundwater at this site. Therefore, nitrate values cannot be obtained from the results of this sampling event. Total nitrate-nitrite results are presented for all the wells. Nitrate-nitrite was not detected at GW-11, UDBP-8, or UDBP-7. Concentrations of $<1 \mathrm{mg} / \mathrm{L}$ were detected at the remaining locations. Ferrous iron was detected in significant quantities only at GW-11, UDBP-8, and UDBP-7. Very low concentrations were detected at UDBP-4 and UDBW-3. Sulfate concentrations were significantly lower at GW-11 than the remaining wells. Methane was present at GW-11 and at very low levels at UDBP-8, UDBP-7, UDBP-4, and UDBW-3. The ORP values were lowest at GW-11, UDBP-8, and UDBP-7. ORP values were measured with a Hydrolab during well purging. Previous experience with this instrument at the INEEL has demonstrated that the ORP probe can require several hours to equilibrate and measure a stable ORP value. For this reason, ORP values are not relied upon as sole indicators of the redox conditions at a particular well.

ARD of TCE and 1,1,1-TCA requires strongly reducing conditions (Vogel and McCarty, 1985; Bouwer, 1994; Weidemeier et al., 1996). A synthesis of the redox parameter results indicates a stronglyreducing zone in the GW-11 area (Figure 4-1). Conditions at GW-11 are sulfate-reducing to methanogenic as indicated by depressed sulfate concentrations and the presence of methane (Table 4-4). Mildly-reducing conditions extend towards MW-3 as evidenced by the presence of relatively depressed dissolved oxygen concentrations and the presence of ferrous iron. Downgradient in the CGA, relatively high dissolved oxygen concentrations indicate aerobic conditions (Figure 4-1; Table 4-4). These results indicate that conditions in the GW-11 area are conducive to reductive dechlorination of TCE and 1,1,1-TCA. Downgradient in the CGA (MW-3 and UDBP-4 area) conditions are favorable for aerobic degradation of less-chlorinated CAHs (DCEs, DCAs, vinyl chloride (VC), CA, and ethene).

\subsection{Chloroethene and Chloroethane Concentrations}

The contaminants of interest during this sampling event were PCE, TCE, and TCA isomers, and their ARD degradation products (DCE and DCA isomers, CA, VC, ethene, and ethane). The results of VOC analysis for these compounds are presented in Table 4-5. PCE and 1,1,2,2-tetrachloroethane (TeCA) were not detected at any location. Parent compounds TCE and 1,1,1-TCA were present in UDBP-8, UDBP-7, MW-2, MW-3, UDBP-4, and UDBW-3 (1,1,1-TCA only). Concentrations of TCE were detected above the MCL at four locations: UDBP-7 $(11 \mu \mathrm{g} / \mathrm{L}), \mathrm{UDBP}-8(9 \mu \mathrm{g} / \mathrm{L}), \mathrm{MW}-3(7 \mu \mathrm{g} / \mathrm{L})$, and UDBP-4 $(6 \mu \mathrm{g} / \mathrm{L})$. 1,1,1-TCA was not detected above the MCL at any of the monitoring locations. 1,1,2-TCA was detected in UDBP-7 and MW-2 at concentrations below the MCL of $5 \mu \mathrm{g} / \mathrm{L}$.

Table 4-4. Redox indicator results. Data are in $\mathrm{mg} / \mathrm{L}$ unless otherwise noted.

\begin{tabular}{lcccccccc}
\hline \multicolumn{1}{c}{ Analyte } & GW-11 & UDBP-8 & UDBP-7 & MW-3 & MW-1 & MW-2 & UDBP-4 UDBW-3 \\
\hline Dissolved Oxygen & 1.57 & 0.13 & 0.17 & 1.13 & 5.38 & 5.18 & 1.76 & 3.05 \\
Nitrate-Nitrite $(\mathrm{N})$ & $\mathrm{ND}$ & $\mathrm{ND}$ & $\mathrm{ND}$ & 0.16 & $0.28 \mathrm{~A}$ & 0.39 & 0.55 & 0.74 \\
Ferrous Iron & 2.3 & 4.68 & 1.26 & $\mathrm{ND}$ & $\mathrm{ND}$ & $\mathrm{ND}$ & 0.07 & 0.05 \\
Sulfate & 9.2 & 68 & 64 & 68 & 55 & 60 & 68 & 84 \\
Methane $(\mu \mathrm{g} / \mathrm{L})$ & 120 & $0.81 \mathrm{AJ}$ & $0.49 \mathrm{AJ}$ & 0 & 0 & 0 & $0.41 \mathrm{~J}$ & $1.3 \mathrm{~J}$ \\
ORP $(\mathrm{mV})$ & 181 & 139 & 182 & 399 & 381 & 534 & 489 & 476 \\
$\begin{array}{l}\text { ND = not detected } \\
\mathrm{A}=\text { average value }\end{array}$ & & & & & & & & \\
\hline
\end{tabular}


Table 4-5. Results of chloroethene and chloroethane $(\mu \mathrm{g} / \mathrm{L})$ and chloride $(\mathrm{mg} / \mathrm{L})$ analyses.

\begin{tabular}{|c|c|c|c|c|c|c|c|c|}
\hline Analyte & GW-11 & UDBP-8 & UDBP-7 & MW-1 & MW-2 & MW-3 & UDBP-4 & UDBW-3 \\
\hline PCE & $\mathrm{ND}$ & $\mathrm{ND}$ & ND & $\mathrm{ND}$ & ND & ND & ND & $\mathrm{ND}$ \\
\hline TCE & $\mathrm{ND}$ & $9 J$ & 11 & $\mathrm{ND}$ & $2 \mathrm{~J}$ & $7 \mathrm{~J}$ & $6 \mathrm{~J}$ & $\mathrm{ND}$ \\
\hline cis-1,2-DCE & $\mathrm{ND}$ & 12 & 35 & $\mathrm{ND}$ & $3 \mathrm{~J}$ & 65 & 50 & $\mathrm{ND}$ \\
\hline trans-1,2-DCE & $6 \mathrm{~J}$ & $\mathrm{ND}$ & $\mathrm{ND}$ & $\mathrm{ND}$ & $\mathrm{ND}$ & $2 \mathrm{~J}$ & $2 \mathrm{~J}$ & $\mathrm{ND}$ \\
\hline 1,1-DCE & $\mathrm{ND}$ & ND & $\mathrm{ND}$ & $\mathrm{ND}$ & $\mathrm{ND}$ & ND & $\mathrm{ND}$ & ND \\
\hline VC & $\mathrm{ND}$ & $\mathrm{ND}$ & $\mathrm{ND}$ & $\mathrm{ND}$ & $\mathrm{ND}$ & ND & $N D$ & $\mathrm{ND}$ \\
\hline Ethene & 4.9 & ND & $\mathrm{ND}$ & ND & ND & $\mathrm{ND}$ & $\mathrm{ND}$ & $\mathrm{ND}$ \\
\hline $1,1,2,2-\mathrm{TeCA}$ & ND & $\mathrm{ND}$ & $\mathrm{ND}$ & $\mathrm{ND}$ & $\mathrm{ND}$ & ND & $\mathrm{ND}$ & $\mathrm{ND}$ \\
\hline $1,1,2-\mathrm{TCA}$ & ND & ND & $1 \mathrm{~J}$ & ND & ND & $1 \mathrm{~J}$ & $\mathrm{ND}$ & $\mathrm{ND}$ \\
\hline $1,1,1-\mathrm{TCA}$ & $\mathrm{ND}$ & $4 \mathrm{~J}$ & $4 \mathrm{~J}$ & $\mathrm{ND}$ & $2 \mathrm{~J}$ & $10 \mathrm{~J}$ & $4 \mathrm{~J}$ & $2 \mathrm{~J}$ \\
\hline 1,1-DCA & $4 \mathrm{~J}$ & $7 \mathrm{~J}$ & 12 & ND & $1 \mathrm{~J}$ & 26 & 18 & $\mathrm{ND}$ \\
\hline 1,2-DCA & $1 \mathrm{~J}$ & $\mathrm{ND}$ & $2 J$ & $\mathrm{ND}$ & $\mathrm{ND}$ & $4 \mathrm{~J}$ & $3 \mathrm{~J}$ & $\mathrm{ND}$ \\
\hline $\mathrm{CA}$ & 85 & $\mathrm{ND}$ & ND & ND & $\mathrm{ND}$ & ND & $1 \mathrm{~J}$ & $\mathrm{ND}$ \\
\hline Ethane & ND & ND & $\mathrm{ND}$ & ND & $\mathrm{ND}$ & ND & ND & ND \\
\hline Chloride & 2.6 & 140 & 120 & $14 \mathrm{~A}$ & 16 & 100 & 41 & 28 \\
\hline $\begin{array}{l}N D=\text { not detected } \\
A=\text { average value } \\
J=\text { estimated value }\end{array}$ & & & & & & & & \\
\hline
\end{tabular}

Two DCE isomers were detected, trans-1,2-DCE and cis-1,2-DCE. Trans-1,2-DCE was detected at GW-11, MW-3, and UDBP-4 at concentrations below the MCL. The highest concentration of any one CAH was in the form of $c i s-1,2-\mathrm{DCE}$, the biologically favored degradation product of ARD, which was detected at all locations except GW-11, MW-1, and UDBW-3. However, concentrations of cis-1,2-DCE were below the MCL at all locations. The other DCE isomer, 1,1-DCE, was not detected during this sampling event. DCA isomers include 1,1-DCA and 1,2-DCA. 1,1-DCA, the biological degradation product of ARD (Vogel and McCarty, 1987), was detected at all wells except MW-1 and UDBW-3. The 1,2-DCA isomer was detected at GW-11, UDBP-7, MW-3, and UDBP-4 at concentrations below the MCL. 1,2-DCA cannot be formed through abiotic or biological transformation of 1,1,1-TCA. For this reason, its presence must be a result of either trace contamination of 1,1,1-TCA or its use as a primary solvent. CA and ethene were present at GW-11 only, with the exception of an estimated value of $1 \mu \mathrm{g} / \mathrm{L}$ at UDBP-4. VC and ethane were not detected at any location. Another ARD degradation product of TCE and 1,1,1-TCA is chloride. Chloride concentrations were significantly elevated at UDBP-8, UDBP-7, MW-3, and to a lesser extent, UDBP-4, with respect to the remaining wells (Table 4-5), however, sodium levels were also elevated in these wells (Appendix A), indicating that dechlorination is not solely responsible for the elevated chloride concentrations.

In summary, parent compounds TCE and/or 1,1,1-TCA were present at all monitoring locations except GW-11 and MW-1 (Figure 4-2). The products of biologically-mediated ARD of TCE and 1,1,1-TCA (cis-1,2-DCE and 1,1-DCA) were detected in relatively high concentrations at UDBP-7, UDBP-8, MW-3, and UDBP-4 (Figure 4-3 [shows cis-1,2-DCE only]). Lower levels of these compounds 
were also found at GW-11 and MW-2. The cis-1,2-DCE distribution also may indicate that the bulk of contamination from the GW-11 area has moved downgradient, as evidenced by the presence of the highest concentrations located at MW-3 rather than GW-11. The abiotic transformation product (trans-1,2-DCE) and 1,2-DCA were detected only at GW-11, UDBP-7, MW-3, and UDBP-4, and at much lower concentrations than cis-1,2-DCE and 1,1-DCA (Figure 4-4). Of the less chlorinated degradation products, chloroethane and ethene were detected only at GW-11 (Figure 4-5). The presence of advanced degradation products chloroethane and ethene at GW-11 indicates that ARD processes are actively occurring in this area. Chloride concentrations were significantly above background at UDBP-8, UDBP-7, MW-3, and UDBP-4 (Figure 4-6), however, the correlation with high sodium concentrations indicates that factors besides dechlorination are probably responsible for the observed distribution.

Complete results of VOC analyses are presented in Appendix A.

\subsection{Water Quality Indicators}

Water quality parameters ( $\mathrm{pH}$, specific conductance, and temperature) were measured with a flow through cell during well purging. The $\mathrm{pH}$ was relatively uniform at near-neutral levels among all the monitoring locations except MW-3, which had a slightly lower value of 6.29 . The specific conductance was significantly elevated at UDBP-8, UDBP-7, and MW-3 with respect to the remaining wells. This is consistent with the elevated chloride concentrations at these wells. The temperature of the groundwater ranged from 13.5 to $15.1^{\circ} \mathrm{C}$.

\subsection{Metals Results}

The results of total and dissolved metals analyses are presented in Appendix A. The species present in the highest concentrations were calcium, magnesium, potassium, and sodium. The predominance of calcium, and to a lesser extent magnesium, is typical of carbonate terranes (Drever 1988). The sodium concentrations correlate with chloride values, with the highest concentrations of both ions being present at UDBP-8, UDBP-7, and MW-3. This correlation suggests that the elevated chloride levels may not be a result of dechlorination but other factors occurring at the Site. Also detected but at significantly lower concentrations were arsenic, barium, chromium, cobalt, copper, iron, lead, manganese, nickel, selenium, vanadium, and zinc. Dissolved arsenic, iron, and manganese were present in significantly higher concentrations at GW-11, UDBP-7, and UDBP-8 than the remaining wells. These species are redox-sensitive and may be being mobilized due to the relatively reducing conditions present at these wells (Drever 1988). Arsenic was present at GW-11 at approximately twice the MCL. However, concentrations at UDBP-7 and UDBP-8 were below the MCL, probably indicating that the change to relatively less reducing conditions downgradient results in the precipitation of arsenic. The elevated iron concentrations are also consistent with the relatively high concentrations of ferrous iron measured at GW-11, UDBP-7, and UDBP-8 (Table 4-4).

\subsection{1,4-Dioxane Concentrations}

The cyclic ether 1,4-dioxane is an additive used in 1,1,1-TCA, typically at concentrations of 2.0-3.5\% (by volume) (Archer 1984). 1,4-dioxane is very hydrophilic, completely miscible in water (Mackay et al. 1993), and appears to be resistant to degradation under anaerobic conditions (Lesage et al. 1990). For these reasons it is very mobile in groundwater systems. If 1,4-dioxane were present in this system, it could serve as a tracer that could be used to assess the extent of biodegradation of TCE and 1,1,1-TCA. 


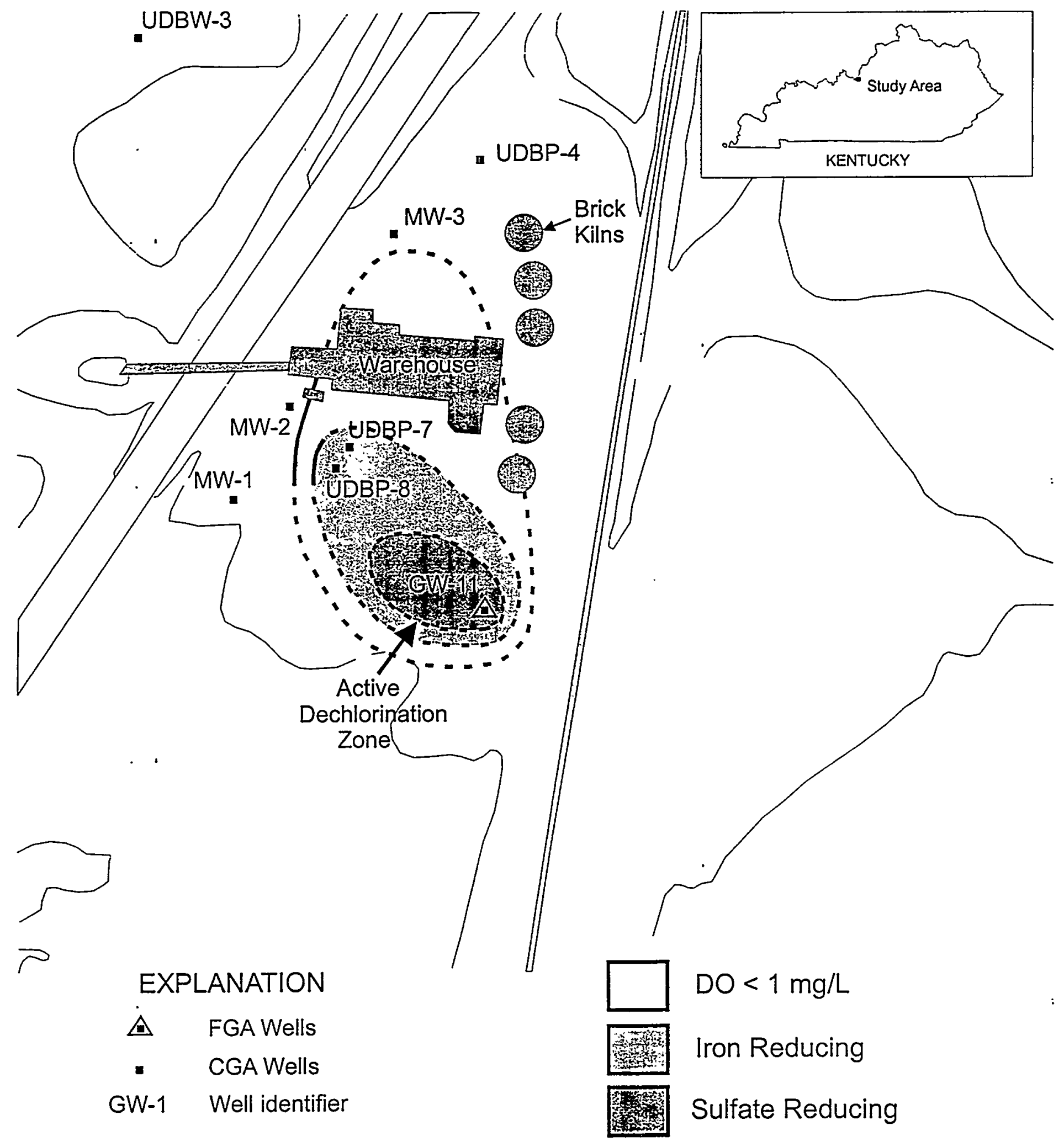

Figure 4-1. Redox conditions. 


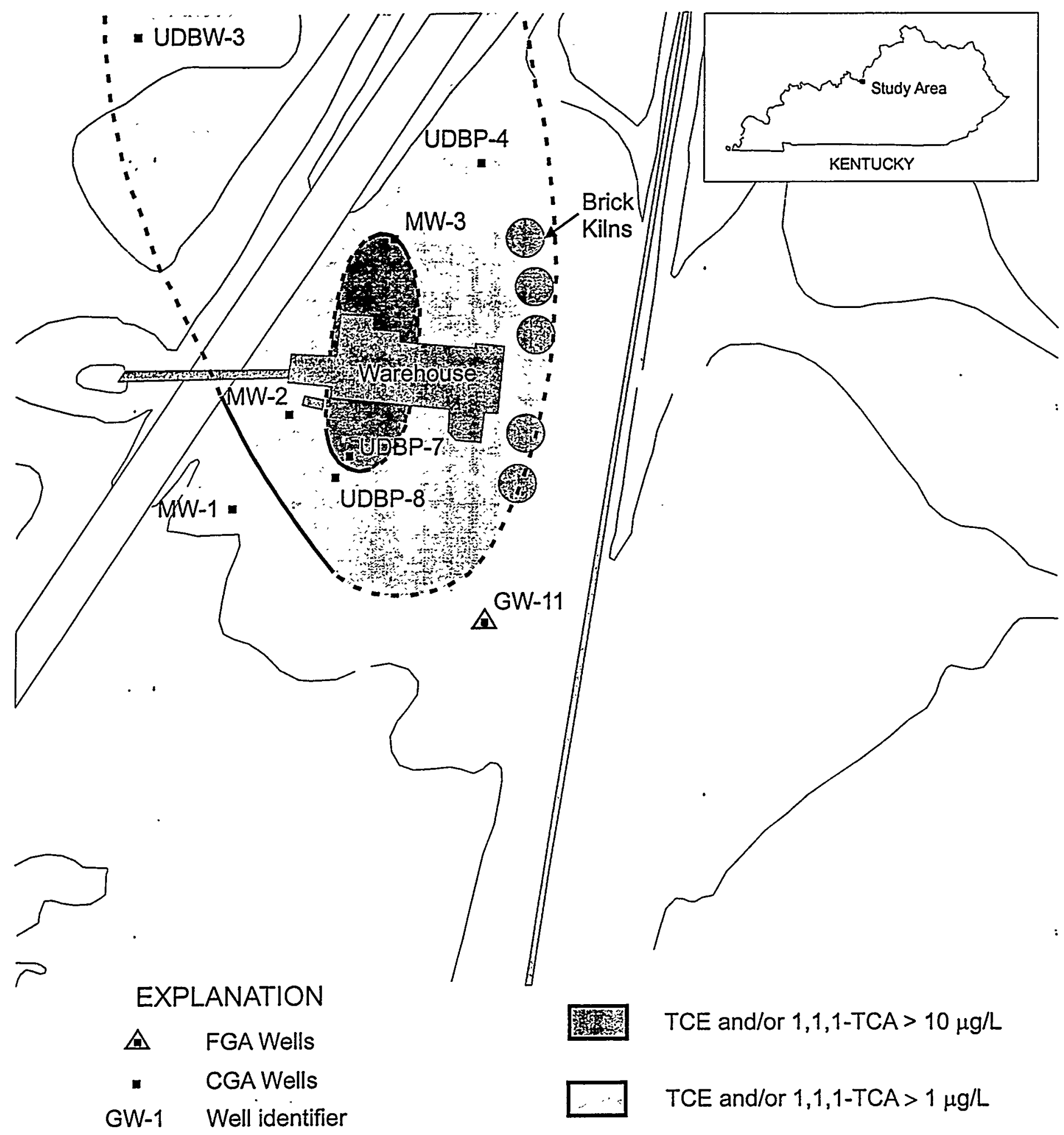

Figure 4-2. TCE and 1,1,1-TCA concentrations. 


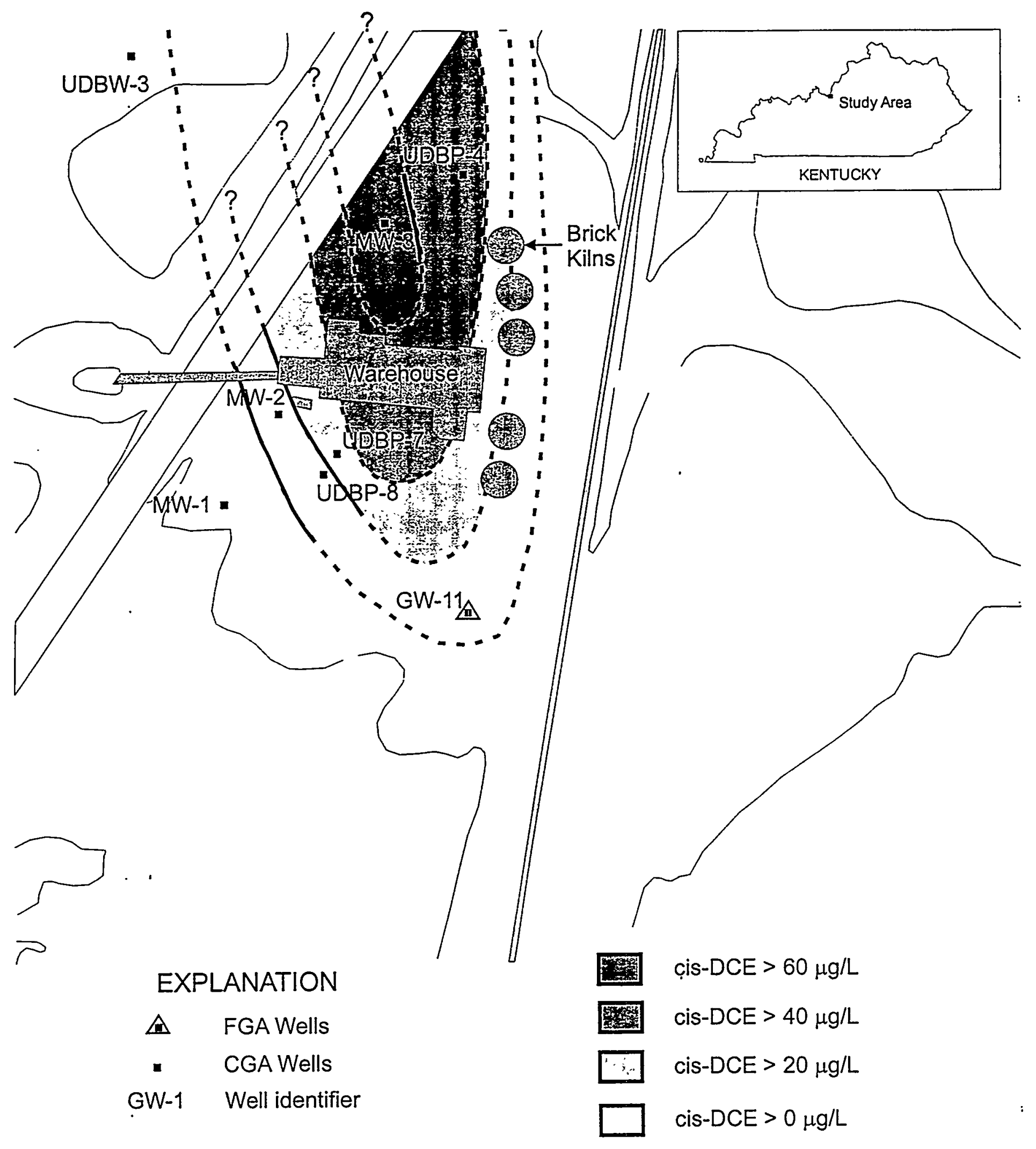

Figure 4-3. Biodegradation product cis-1,2-DCE. 


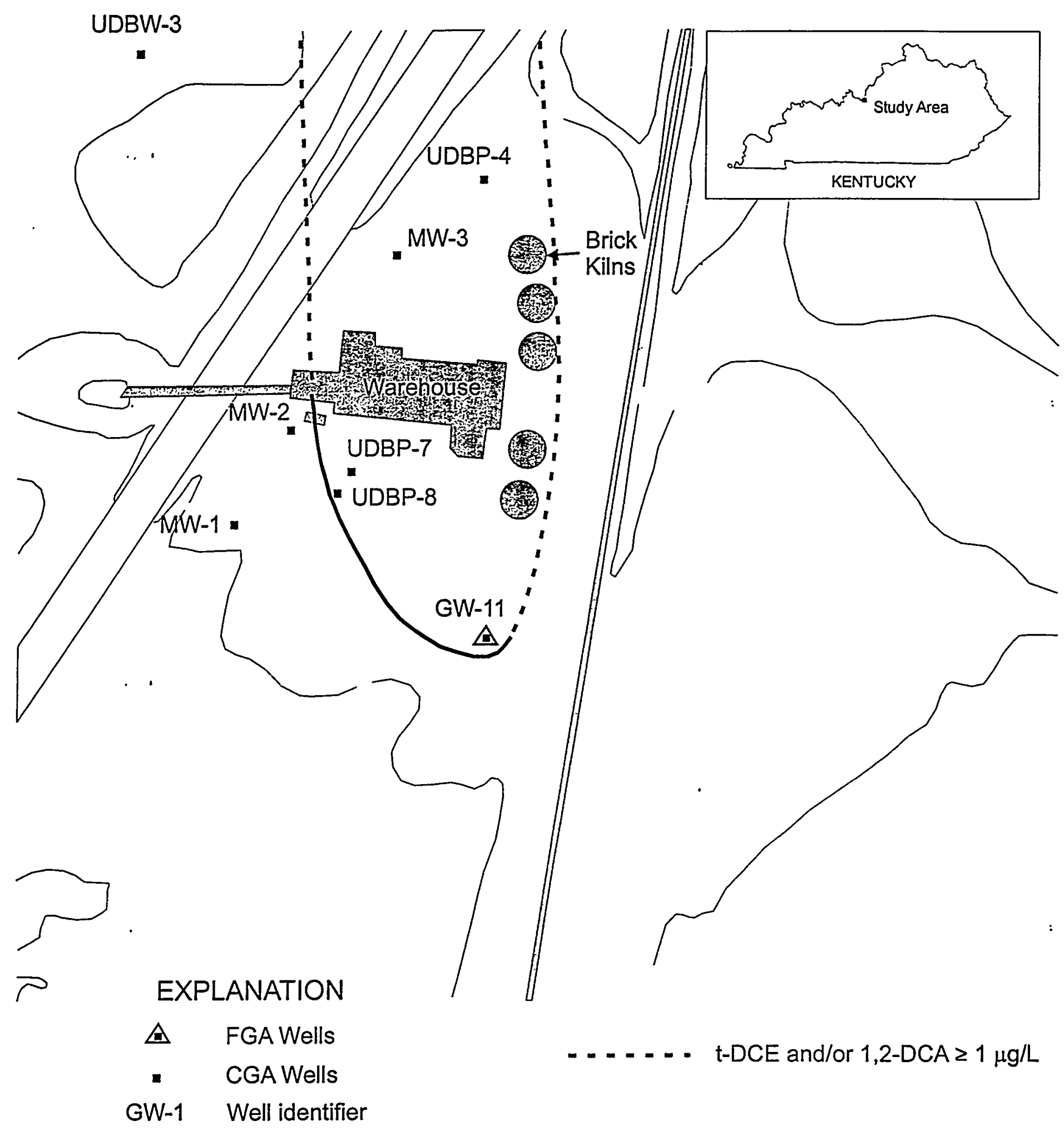

Figure 4-4. Abiotic degradation products trans-DCE and 1,2-DCA. 


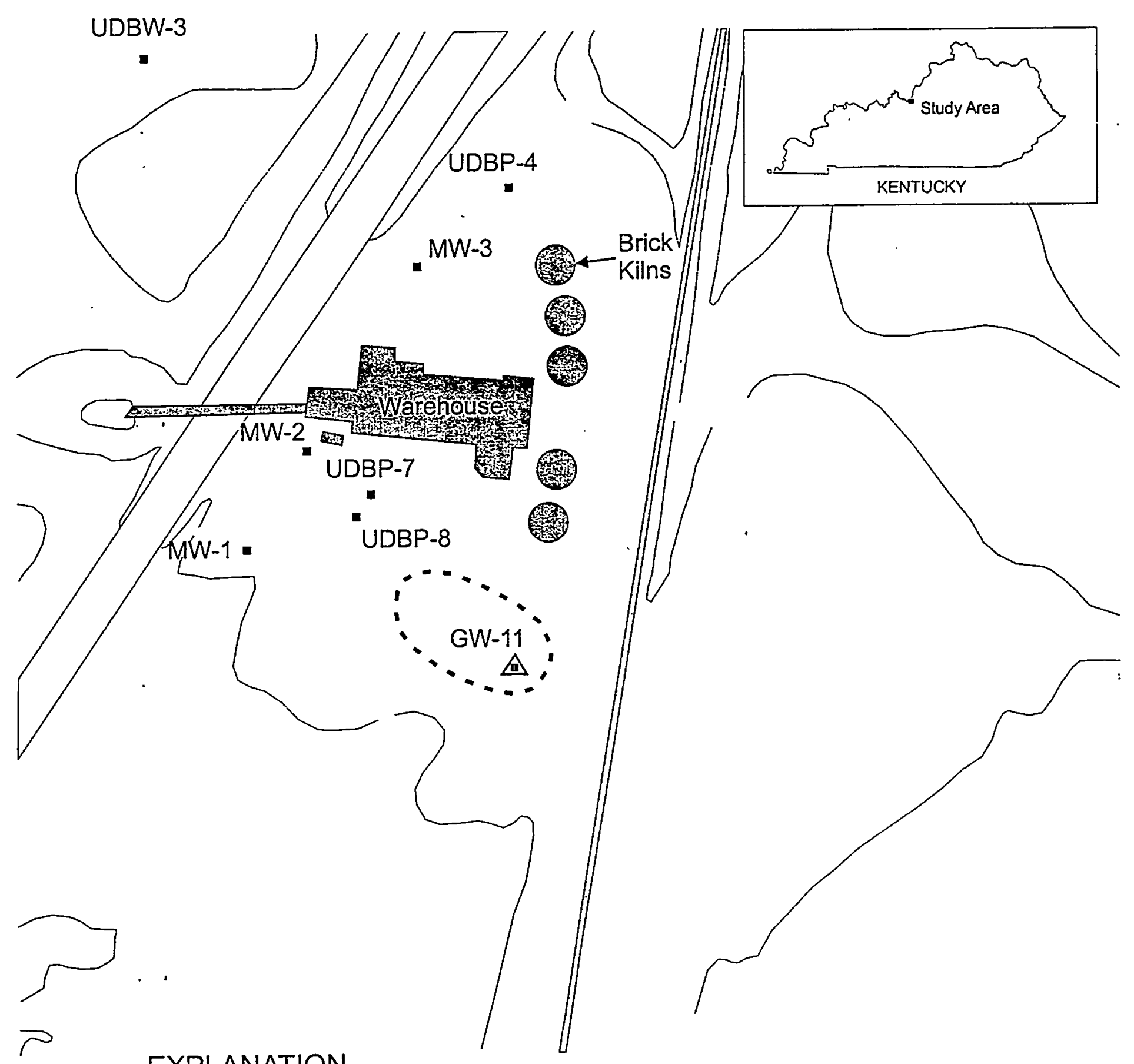

\section{EXPLANATION}

$\triangle \quad$ FGA Wells

- CGAWells

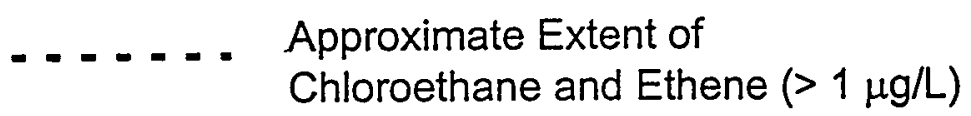

GW-1 Well identifier

Figure 4-5. Advanced degradation products chloroethane and ethene. 


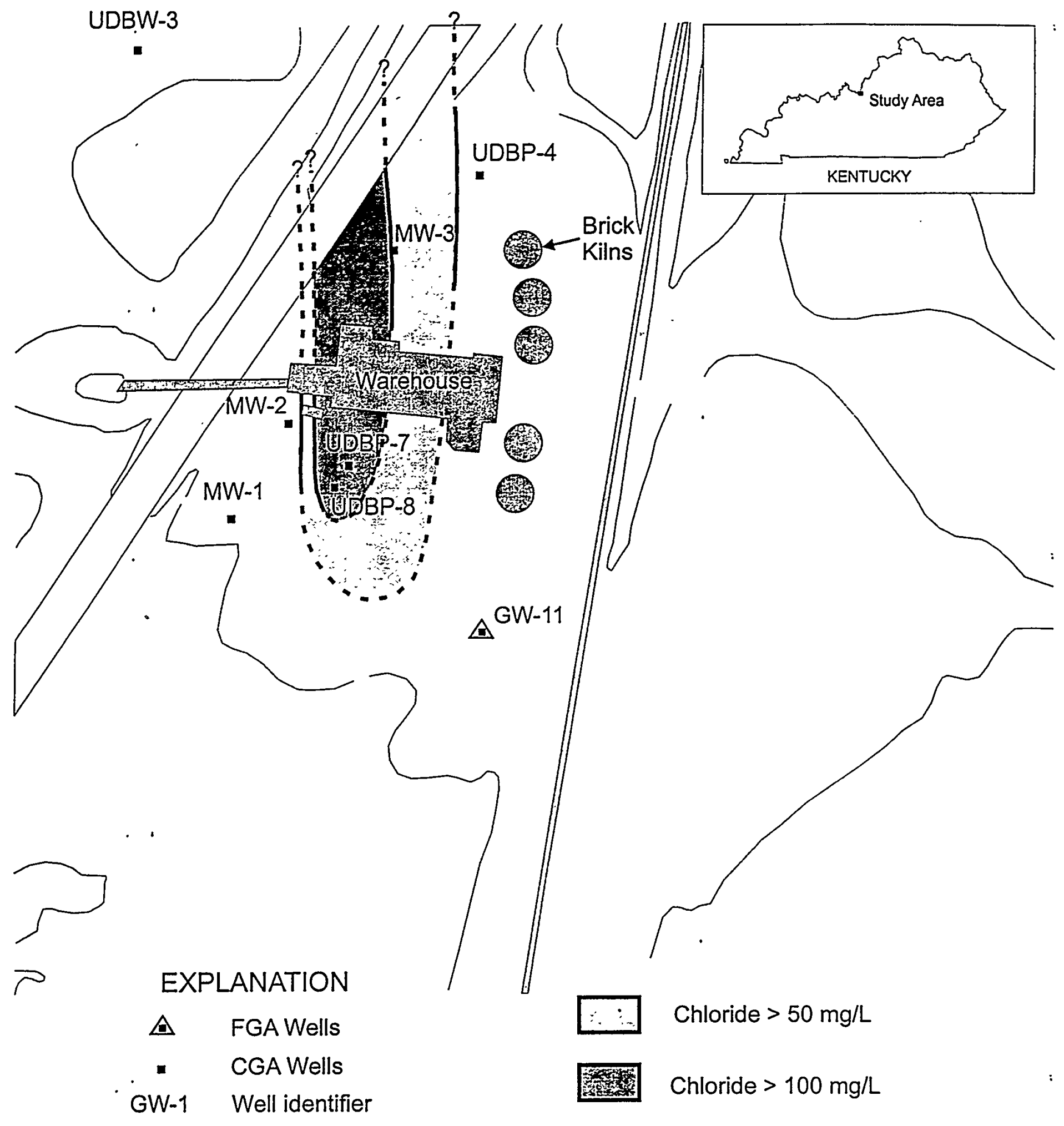

Figure 4-6. Dechlorination product chloride. 
1,4-dioxane was detected at only two locations: GW-11 and UDBP-4 (Table 4-7). Unfortunately, it is analytically difficult to measure aqueous concentrations less than $150 \mu \mathrm{g} / \mathrm{L}$ (Lesage et al. 1990); the detection limit in this study was $50 \mu \mathrm{g} / \mathrm{L}$. For this reason, the lower concentrations of 1,4-dioxane that would be expected are not detectable with the analytical method available.

Table 4-6. Water quality parameters.

\begin{tabular}{|c|c|c|c|c|c|c|c|c|}
\hline Analyte & GW-11 & UDBP-8 & 3 UDBP-7 & MW-3 & MW-1 & MW-2 & UDBP-4 & UDBW-3 \\
\hline $\mathrm{pH}$ & 6.98 & 6.84 & 6.79 & 6.29 & 6.85 & 6.78 & 6.91 & 6.87 \\
\hline $\begin{array}{l}\text { Specific } \\
\text { Conductance } \\
\left(\mu \mathrm{S} / \mathrm{cm} @ 25^{\circ} \mathrm{C}\right)\end{array}$ & 735 & 1260 & 1190 & 1133 & 743 & 668 & 830 & 903 \\
\hline Temperature $\left({ }^{\circ} \mathrm{C}\right)$ & 14.5 & 15.1 & 14.3 & 14.2 & 14.7 & 13.5 & 13.8 & 14.9 \\
\hline Analyte & GW-11 & UDBP-8 & UDBP-7 & MW-3 & MW-1 & MW-2 & UDBP-4 & UDBW-3 \\
\hline 1,4-Dioxane & $12 \mathrm{~J}$ & ND & ND & ND & ND & $\mathrm{ND}$ & $23 \mathrm{~J}$ & $\mathrm{ND}$ \\
\hline $\begin{array}{l}N=\text { presumptive det } \\
N D=\text { not detected } \\
A=\text { average value } \\
J=\text { estimated value }\end{array}$ & tion & & & & & & & . \\
\hline
\end{tabular}




\section{QUALITY ASSURANCE}

Quality assurance/quality control (QA/QC) objectives as stated in field sampling plan (Martin et al., 1999) called for the collection of groundwater samples in accordance with the Environmental Compliance Branch Standard Operating Procedures and Quality Assurance Manual (EPA, 1996), and National Water-Quality Assessment Program (NAWQA) Ground-Water Data-Collection Protocols and Procedures (Koterba et al., 1995). In addition, the field sampling plan specified the frequency of duplicates, trip blanks, and rinsate samples (Martin et al., 1999). Duplicates and equipment rinsate samples were submitted for a randomly chosen laboratory schedule. Results of duplicate and equipment rinsate analyses are presented in Table 5-1 and Table 5-2, respectively. Results presented in Table 5-1 indicate that results below the detection limit were obtained for both duplicates for 1,4-dioxane, ethane, and ethene results. Methane concentrations in both duplicates were reported below $1 \mu \mathrm{g} / \mathrm{L}$ and were qualified as approximate values.

Groundwater samples were analyzed by either the EPA Water Quality Laboratory or a contract laboratory through the EPA Contract Laboratory Program. Quality assurance/quality control procedures are established for the EPA Water Quality Laboratory as specified in the Analytical Support Branch Operations and Quality Control Manual (EPA, 1997). In addition, EPA Region 4 participates in a Performance Evaluation Program for all water parameters. Contract laboratory guidance is established in Exhibit E of USEPA Contract Laboratory Program Statement of Work for Organic Analysis, MultiMedia, Multi-Concentration OLM04.2 and USEPA Contract Laboratory Program Statement of Work for Inorganics Analysis, Multi-Media, Multi-Concentration, ILM04.0.

Table 5-1. Duplicate analyses $(\mu \mathrm{g} / \mathrm{L})$.

\begin{tabular}{ccc}
\hline \multicolumn{1}{c}{ Analyte } & Value 1 & Value 2 \\
\hline 1,4-dioxane & $\mathrm{ND}$ & $\mathrm{ND}$ \\
Methane & $0.94 \mathrm{AJ}$ & $0.67 \mathrm{~J}$ \\
Ethane & $\mathrm{ND}$ & $\mathrm{ND}$ \\
Ethene & $\mathrm{ND}$ & $\mathrm{ND}$ \\
\hline $\mathrm{ND}=$ not detected & & \\
$\mathrm{A}=$ average value & & \\
$\mathrm{J}=$ estimated value & & \\
\hline
\end{tabular}

Table 5-2. Rinsate sample results.

\begin{tabular}{cc}
\hline Analyte & UDBW-1 Rinsate \\
\hline 1,4-dioxane & ND \\
Methane & ND \\
Ethane & ND \\
Ethene & ND \\
ND = not detected & \\
J = estimated value & \\
\hline
\end{tabular}




\section{DISCUSSION}

This section discusses the results presented in Section 4. Section 6.1 discusses the distribution of contaminants observed in October 1999. Sections 6.2 and 6.3 discuss the results in the context of the original goals of the sampling event: FGA conditions (Section 6.2), and an axial cross-section and downgradient CGA transect (Section 6.3).

\subsection{Distribution of Contaminants}

The contaminant distributions and conditions presented in Figures 4-2 to 4-6 indicate that the flowpath from the presumed source area in the FGA at GW-11 is more northerly (toward MW-3 and UDBP-4) rather than to the northwest (toward MW-2) as previous studies indicated. A number of lines of evidence support this interpretation. The presence of 1,4-dioxane at GW-11 and UDBP-4 indicate the source of contamination located at GW-11 migrates to UDBP-4. This is also supported by the distribution of cis-1,2-DCE at the Site (Figure 4-3). The groundwater flowpath may be influenced by the bedrock surface that slopes down to the north from GW-11. It also may be affected by seasonal fluctuations in recharge from infiltration of precipitation through the FGA and influx to the CGA from the Ohio River (USGS, in preparation). For this reason, the measured contaminant concentrations and distribution may be influenced by the time of year samples were collected. The seasonal effect on contaminant concentrations and the hydraulic gradient should be determined with future sampling events (discussed below).

\subsection{Anaerobic Reductive Dechlorination in the FGA}

Redox conditions in the FGA as indicated by results obtained from GW-11 are favorable for ARD of TCE and 1,1,1-TCA (sulfate-reducing to methanogenic) (Figure 4-1). Electron donor concentrations are higher in the GW-11 area than in the CGA, also indicating that ARD is favorable in this area. There appears to be an active zone of dechlorination centered at GW-11 as evidenced by the absence of TCE and 1,1,1-TCA and the presence of advanced degradation products 1,2-DCA, chloroethane, and ethene. This dechlorination area probably also includes $\mathrm{PZ}-4$, as evidenced by the detection of $\mathrm{CA}$ at this location in previous investigations (USGS, in preparation). The presence of TCE and 1,1,1-TCA and less chlorinated degradation products downgradient indicate that this historical degradation has not been sufficient to prevent the migration of some chlorinated compounds into the CGA. Concentrations of TCE migrating into the CGA are low, but are slightly above the MCL of $5 \mu \mathrm{g} / \mathrm{L}$. This flux may be affected by seasonal changes in recharge. The effect of these seasonal changes on contaminant concentrations should be determined in order to fully understand the magnitude of the flux from the FGA to the CGA (discussed below). The natural ARD process in the FGA may be limited by a lack of adequate electron donor. $A$ lack of biological nutrients may also limit ARD processes.

\subsection{Geochemical Conditions in the CGA}

Monitoring locations in the CGA were selected to examine two sections through the plume: an axial cross-section and a downgradient transect, and an off-site monitoring location. These locations were selected using the following assumptions: the source area was located at GW-11 and the groundwater flow direction was to the northwest from this source area (as shown in Figure 1-1). As stated above, the observed flow direction appears to be from GW-11 to the north-northwest. For this reason, the appropriate axial cross-section is from GW-11 towards MW-3 with UDBP-7, UDBP-8, and UDBP-4 being slightly off-set from the axis. The CGA transect MW-1, MW-2, MW-3, and UDBP-4 intersects the axial transect obliquely rather than at a right angle as anticipated. UDBW-3 would have provided an excellent monitoring location to detect the extent of off-site contaminant migration if the flowpath was to 
the northwest as anticipated. However, given the observed contaminant distribution and migration, locations north of MW-3 and UDBP-4 may be more appropriate.

As stated above, conditions at GW-11 are sulfate-reducing to methanogenic and there is an active dechlorination zone in this area. Moving downgradient from GW-11, iron-reducing conditions extend to UDBP-7 and UDBP-8 and a zone of depressed oxygen concentrations extends toward MW-3

(Figure 4-1). The distribution of biologically-favored degradation products cis-1,2-DCE and 1,1-DCA indicate that products of dechlorination are migrating to the north from the GW-11 area (Figure 4-3). The abiotic degradation products, trans-1,2-DCE and 1,2-DCA, were also detected along this flowpath at very low concentrations (Figure 4-4). The distribution of ARD degradation products may also suggest that the majority of the TCE and 1,1,1-TCA source around GW-11 may be removed as the cis-1,2-DCE and 1,1-DCA center of mass appears to have migrated toward MW-3. However, the presence of ethene and CA at GW-11 indicate active degradation, suggesting that some source material may still be present. Before conclusions regarding the extent of source degradation can be addressed, more sampling in the FGA around GW-11 needs to be conducted. This observation will have important implications for the selection of a remedial remedy (discussed below).

The downgradient CGA transect includes MW-1, MW-2, MW-3, and UDBP-4. Conditions at MW-1 and MW-2 are aerobic and show no evidence of reductive dechlorination. MW-3 intersects the axial flowpath from GW-11 and conditions are characterized by high concentrations of cis-1,2-DCE and 1,1-DCA (Figure 4-3). UDBP-4 also has high concentrations of these compounds but appears to be on the other side of the highest concentrations at MW-3, thus helping to define the northeast side of the plume. More monitoring east of MW-3 is necessary in order to better define the eastern boundary of the contamination in this area.

The off-site monitoring point UDBW-3 is characterized by aerobic conditions and very low concentrations of 1,1,1-TCA. As stated above, this location may not be the most appropriate location for detecting off-site migration given the observed groundwater flowpath. If contaminants are migrating off-site, the highest concentrations are probably located to the east of UDBW-3. 


\section{CONCLUSIONS}

The data collected during the October 1999 sampling event have led to the following conclusions with respect to the extent of biodegradation and contaminant migration:

- Redox conditions around GW-11 are favorable for ARD (sulfate-reducing to methanogenic). Relatively reducing conditions extend into the CGA towards UDBP-7 and UDBP-8. The remainder of the CGA is aerobic (dissolved oxygen $>1 \mathrm{mg} / \mathrm{L}$ ) (Figure 4-1).

- An active dechlorination zone exists at GW-11 as evidenced by the absence of TCE and 1,1,1-TCA and the presence of advanced degradation products chloroethane and ethene. Primary contaminants TCE and 1,1,1-TCA and less chlorinated degradation products migrate downgradient into the CGA at concentrations near or slightly above MCLs (Figures 4-2 and 4-3).

- Less-chlorinated degradation products $\mathrm{CA}$ and $\mathrm{VC}$ are not present downgradient in the aerobic CGA.

Based on these conclusions, the following hypotheses are proposed:

- The soil removal activities conducted in 1988 may have been effective in removing the bulk of chloroethene contamination from the GW-11 area.

- $\quad \mathrm{ARD}$ has and appears to continue to degrade remaining chlorinated compounds in the FGA in the GW-11 area. This degradation is sufficient to prevent the migration of CAHs into the CGA at concentrations above the MCLs, with the exception of TCE, which is present at approximately twice the MCL of $5 \mu \mathrm{g} / \mathrm{L}$.

- Natural aerobic biodegradation of ARD degradation products may be occurring in the CGA.

In order to confirm these hypotheses, additional sampling is required (described in Section 9). If the results from the additional sampling support the above hypotheses, then a monitored natural attenuation (MNA) remedy may be sufficient to remediate remaining contamination at the Site. This and other possible remedies are described below. 


\section{DATA GAPS}

Before recommendations regarding remedial activities made, data gaps need to be addressed. The October 1999 sampling activity has resulted in the following data gaps:

- Data Gap 1: Effect of seasonal recharge on contaminant concentrations. Previous investigations indicated that the contaminant concentrations fluctuate seasonally (USGS in preparation). The October 1999 sampling event was conducted following an extremely dry summer season. The effect of renewed recharge through the FGA could result in a remobilization of contaminants and cause concentrations to rise. Changing recharge could also result in a shift in the local flow direction. This information will be very important to the evaluation of the extent of source degradation, which will in turn effect the selection of the appropriate remedial remedy.

- Data Gap 2: FGA conditions. The conditions in the FGA were evaluated based on data from a single monitoring location (GW-11). Obviously, in order to determine the extent of FGA contamination, to define the extent of the dechlorination zone, and to evaluate the extent of source degradation, more monitoring in the FGA, including groundwater and possibly soil gas sampling, are necessary. Again, this information has important implications for assessment of source degradation and subsequent remedial actions.

- Data Gap 3: Conditions along the GW-11 $\rightarrow$ MW-3 flowpath. The contaminant distributions and conditions indicate that the flowpath from the presumed source area in the FGA at GW-11 is more northerly (toward MW-3 and UDBP-4) rather than to the northwest (toward MW-2) as previous studies indicated. This flowpath may be influenced by the bedrock surface in this area. It also may be affected by seasonal fluctuations in recharge from infiltration of precipitation through the FGA and influx to the CGA from the Ohio River (USGS, in preparation). More monitoring locations in the area both north and south of the warehouse (east of MW-3 and UDBP-7) are necessary in order to define the eastern boundary of the plume as it migrates towards MW-3 and UDBP-4.

- Data Gap 4: The extent of aerobic degradation in the CGA. In order to determine the extent of aerobic degradation of ARD reaction products in the CGA and off-site contaminant migration, monitoring locations north and west of MW-3 and UDBP-4 are necessary. The concentrations of ARD degradation and mineralization products (DCEs, DCAs, VC, CA, ethene, and carbon dioxide) will be used to determine the fate of contamination in the CGA. 


\section{RECOMMENDATIONS}

\subsection{Additional Field Activities}

Additional field activities are necessary in order to address the data gaps stated in the previous section. Groundwater sampling should be conducted during relatively wet conditions (May-June) to ensure adequate recharge to FGA wells and to evaluate the effects of seasonal recharge on contaminant concentrations (Data Gap 1). In order to assess the extent of FGA contamination more sampling in the area around GW-11 is required (Data Gap 2). Addressing Data Gaps 1 and 2 can be accomplished through the rehabilitation of existing wells and/or the installation of new monitoring wells. Soil gas sampling could also be used to determine the extent of FGA contamination, define the extent of the FGA dechlorination zone, and to define the extent of source degradation. The use of soil gas sampling would mitigate the problem of inadequate recharge to the FGA while still providing the data necessary to address data gaps. Groundwater sampling in the CGA will be necessary to address Data Gaps 3 and 4. This groundwater sampling may require additional monitoring wells both north and south of the warehouse.

Future sampling activities could use the same suite of analytes used in this sampling event with two modifications. In order to determine nitrate concentrations, it will be necessary to use a nitrate field test kit rather than a field nitrite and lab total nitrate/nitrite analysis. The detection limit and precision of the nitrite field test kit are not adequate to determine nitrite concentrations at this site. The nitrate field test kit may produce a hazardous waste. The appropriate waste disposition will need to be resolved prior to future sampling activities if this kit is to be used. Also, it may not be worthwhile to measure 1,4-dioxane concentrations. As stated above, the analytical method currently available is insufficient to detect low concentrations of the compound $(<50 \mu \mathrm{g} / \mathrm{L})$. The low concentrations of 1,4-dioxane detected during the October 1999 sampling event indicate that expected concentrations are below the method detection limit available. For this reason, it is suggested that 1,4-dioxane not be included in future sampling activities until a lower detection limit is available.

The following describes the activities necessary to address the above data gaps.

1. Evaluation of existing monitoring wells. The evaluation includes wells sampled during the October 1999 event and additional wells (Table 9-1; Figure 9-1). Wells will be evaluated by collecting water level measurements and pumping the wells and monitoring recovery. If one can be obtained, a borehole camera may be used to perform visual inspections. If an obstruction is present in the well, attempts may be made to physically clear it or the well may be deemed unsamplable. During this activity, possible existing wells off-site will be located and evaluated. The results of this reconnaissance will be used to select wells for the sampling event and will determine the necessary number of new wells that may be required.

2. Monitoring well installation in Areas A, B, C. This activity includes installing new monitoring wells in two or three areas: the eastern portion of the Site (Area A), in the kiln area (Area B), and if necessary west of GW-11 in Area C (Figure 9-1). The number and locations of these new wells will largely depend on the success of the status of existing monitoring wells at the Site, but should not exceed 6 new wells.

3. Groundwater sampling. Groundwater sampling of the selected monitoring wells would conducted to address the above data gaps. Monitoring locations will be selected following the initial monitoring well evaluation and installation of additional wells. Sampling must be 
conducted during the relatively wet period of May-June in order to ensure adequate recharge to the FGA wells.

4. Soil gas sampling in the FGA. Soil gas sampling would be conducted to address Data Gap 2. Analytes would include both chlorinated aliphatic hydrocarbons (chloroethenes and chloroethanes), chlorinated and non-chlorinated aromatic compounds (petroleum hydrocarbons), ethene, ethane, methane, dissolved oxygen, and carbon dioxide. Sampling should be focused on known or suspected source areas (GW-11 and GW-4).

5. Monitoring well installation in Areas $\mathbf{D}$ and $\mathbf{E}$. Installation of additional off-site monitoring locations may be conducted only if existing suitable locations are not located and/or contaminant concentrations at MW-3, UDBP-4, and MW-4 are high enough that the downgradient edge of the plume needs to be defined. The timing of this activity, if conducted, will be determined at a later date.

Table 9-1. Existing wells to be evaluated.

\begin{tabular}{lll}
\hline \multicolumn{1}{c}{ Well } & Zone & \\
\hline GW-11 extraction well & FGA & Piped for pump and treat facility \\
GW-6 & FGA & Dry \\
GW-11 & FGA & Ok \\
PZ-4 & FGA & Dry \\
MW-5 & FGA & Unknown \\
UDBW-1 & FGA & Dry \\
UDBW-2 & FGA & Dry \\
GW-1 & FGA & Possibly contains surface water; may indicate \\
& & compromised casing or annular seal \\
GW-3 & CGA & Clogged screen; uncapped \\
MW-4 & CGA & Unknown \\
UDBP-5 & CGA & Unknown \\
UDBP-6 & CGA & Unknown \\
GW-5 & CGA & Unknown \\
GW-2 & CGA & Unknown \\
UDBP-7 & CGA & Ok \\
UDBP-8 & CGA & Ok \\
UDBP-4 & CGA & Ok \\
MW-1 & CGA & Ok \\
MW-2 & CGA & Ok \\
MW-3 & & Ok \\
UDBW-3 & Ok \\
\hline
\end{tabular}




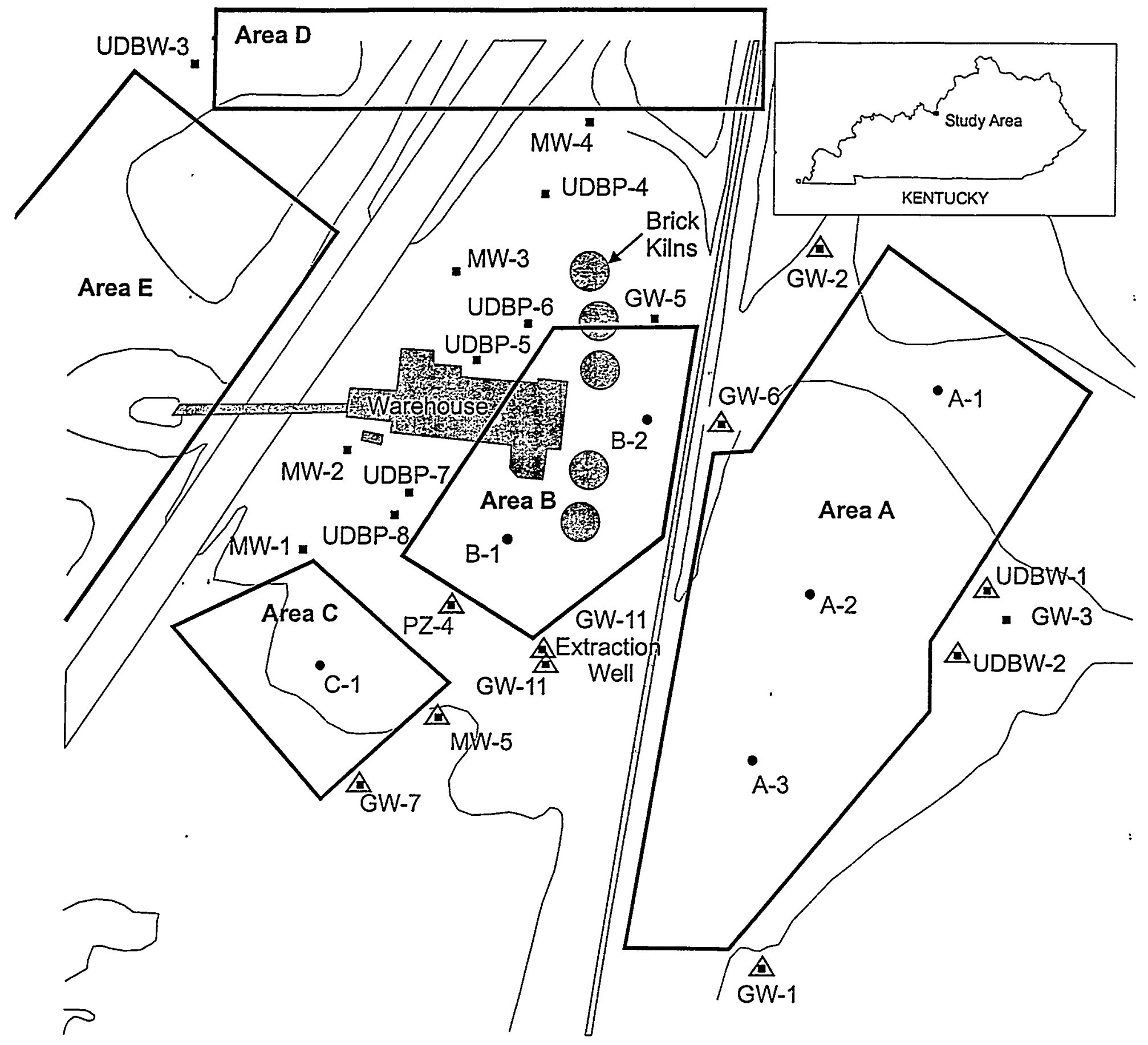

\section{EXPLANATION}

$\triangle \quad$ FGA Wells to be Evaluated

- CGA Wells to be Evaluated

- $\quad$ Proposed New Well Locations

GW-1 Well identifier

Figure 9-1. Site map showing monitoring wells to be evaluated for future sampling and generalized locations for proposed additional monitoring wells. 


\subsection{Remedial Activities}

Once the data gaps defined in Section 8 have been addressed through additional sampling, the appropriate remedy can be chosen. Recommendations for remedial activities are difficult at this time due to the data gaps scribed above. The following scenarios represent possible remedial actions for this Site following the collection of the appropriate data. The appropriate course of action will largely depend on the status of the source area around GW-11 and other source areas discovered at the Site (if any). Four scenarios are presented: two if no source area remains and two if a source area remains. The options are presented in the order from most desirable to least desirable.

If subsequent sampling rounds indicate complete source removal from the GW-11 area through soil removal action and/or biodegradation processes and no other source areas are found, then the following options are available:

- Monitored Natural Attenuation (MNA). If the source has been remediated and the flux of degradation products to the CGA remains at or near MCLs, MNA may be adequate to address remaining chloroethene and chloroethane contamination at the Site. This remedy is desirable in that no additional engineered remedial actions are required. However, groundwater modeling and continued monitoring would be necessary. The seasonal effect of recharge on contaminant concentrations and flux must be better understood in order to consider this action.

- Enhanced Bioremediation (CGA). Enhanced aerobic or anaerobic bioremediation could be implemented in the CGA to remediate current contamination. Bioremediation is desirable in that contaminant mass is destroyed rather than removed from solution (as occurs with sorption processes or with pump and treat). An enhanced bioremediation remedy would probably require laboratory studies in order to select the appropriate amendments. This remedy would also require an engineered amendment delivery system and continued monitoring of the degradation processes.

If subsequent sampling rounds indicate that a source of contamination remains in the GW-11 area (or other source areas are located), then the following options are available:

- Enhanced Bioremediation (FGA and CGA). ARD processes can be enhanced through the addition of an electron donor and nutrients (if necessary). In this scenario, enhanced bioremediation is used to drive ARD throughout the aquifer system, resulting in complete removal of chloroethene and chloroethane contamination at the Site. The implementation of enhanced bioremediation may require laboratory studies to select the appropriate electron donor. Also, adequately delivering the appropriate electron donor to the FGA may be difficult due to the low hydraulic conductivity of the unit.

- Enhanced Bioremediation (FGA) and Monitored Natural Attenuation (CGA). Natural ARD processes can be enhanced through the addition of an electron donor and nutrients (if necessary). In this scenario, enhanced bioremediation is sufficient to stop the flux of contaminants from the FGA to the CGA. MNA would be implemented in the CGA to monitor the dispersion and degradation of contaminants currently in the CGA. The difficulties associated with enhanced bioremediation at this Site are described above. In order to implement MNA, groundwater modeling and monitoring would be necessary in order to ensure that processes were sufficient to reduce the concentration of contaminants to acceptable levels. 
- Enhanced Bioremediation (FGA) and Pump and Treat (CGA). Natural ARD processes can be enhanced through the addition of an electron donor and nutrients (if necessary). The difficulties associated with this remedy are described above. Pump and treat could be used to remove contaminants from the CGA until the flux from the FGA had been stopped. Implementation of pump and treat would require the construction and installation of a groundwater extraction and treatment system at the Site. The performance of this system would have to be monitored. Also, additional security measures at the Site would need to be instituted in order to protect the equipment from vandalism.

\subsection{Site Conditions}

Any remedial remedy will require continued monitoring at the Site in some form. The October 1999 sampling event revealed a number of site conditions that require attention in order to facilitate these future monitoring activities. Currently the wells at the Site are difficult to identify. Some of them have a Kentucky Division of Water monitoring well sticker on them; however, they do not appear to include the name of the well. A uniform system of identification markers on the wells needs to be installed to properly identify wells in the field. Following proper identification, a Site map can be constructed using a GPS to properly locate each well. Access to the wells needs to be maintained to allow for future routine monitoring. This includes keeping the pathways free of debris and tall foliage so wells can be accessed with sampling vehicles.

A number of the wells at the Site appear to be clogged, either with foreign material entering the well from above or with sediment from the formation clogging the screen. The wells need to be protected with caps over the inner casing and an outer protective casing with a lock to prevent contamination by rainwater or other debris from the surface. A number of the wells at the Site have outer casings that are in very poor condition and may need to be replaced.

The physical condition of the wells can be used with the information identified above (well identification markers and locations) and the well completion information to assemble a Site map with a complete list of the usable wells, their condition, and screen intervals. This information will be crucial to selecting viable wells for long term monitoring. 


\section{REFERENCES}

Anderson, W. R. and A. K. Bomberger, 1986, Remedial Investigation Report, Distler Brickyard West Point, Kentucky, NUS Corporation, Unpublished technical report, U.S. Environmental Protection Agency Region 4, Atlanta, Georgia.

Archer, W. L., 1984, "A laboratory evaluation of 1,1,1-trichloroethane-metal-inhibitor systems", Werkstoffe und Korrosion, Vol. 35, pp. 60-9.

Barbee, Gary C., 1994, "Fate of chlorinated aliphatic hydrocarbons in the vadose zone and ground water," Ground Water Monitoring and Remediation, Vol. 9, no. 1, pp.129-140.

Bouwer, E. J., 1994, "Bioremediation of Chlorinated Solvents Using Alternate Electron Acceptors," Handbook of Bioremediation, Lewis Publishers, pp. 149-175.

de la Pena, G. R., 1989, Draft Revised Geologic Interpretation, Distler Brickyard Site, Hardin County, Kentucky, EBASCO Services Incorporated, Unpublished technical report, U.S. Environmental Protection Agency Region 4, Atlanta, Georgia.

Drever, J. I., 1988, The Geochemistry of Natural Waters, Prentice Hall, Englewood Cliffs, New Jersey.

Duffey, J. T., Lee, C. H., and M. Warner, 1983, Geology/Hydrology and Monitoring Well Installation, Distler's Brickyard Site, Jefferson [sic] County, Kentucky, NUS Corporation, Unpublished technical report, U.S. Environmental Protection Agency Region 4, Atlanta, Georgia.

EPA, 1997, Analytical Support Branch Operations and Quality Control Manual, Science and Ecosystem Support Division, Region 4, Athens, GA, Revision 1.

EPA, 1998, Five Year Review Report Distler Brickyard Superfund Site, Hardin County, Kentucky, Unpublished technical report, U.S. Environmental Protection Agency Region 4, Atlanta, Georgia.

EPA, 1999, USEPA Contract Laboratory Program Statement of Work for Organic Analysis, Multi-Media, Multi-Concentration, Document Number OLM04.2.

EPA, 1999, USEPA Contract Laboratory Program Statement of Work for Inorganic Analysis, MultiMedia, Multi-Concentration, Document Number ILM04.0.

Koterba, M. T., Wilde, F. D., and W. W. Lapham, 1995, Ground-Water Data-Collection Protocols and Procedures for the National Water-Quality Assessment Program: Collection and Documentation of Water-Quality Samples and Related Data, U.S. Geological Survey Open File Report 95-399.

Lesage, S., R. E. Jackson, M. W. Priddle, and P. G. Riemann, 1990, “Occurrence and fate of organic solvent residues in anoxic groundwater at the Gloucester Landfill, Canada," Environmental Science and Technology, Vol. 24, no. 4, pp. 559-566.

Mackay, D., W. Y. Shiu, and K. C. Ma, 1993, Illustrated Handbook of Physical-Chemical Properties and Environmental Fate of Organic Chemicals. Volume III: Volatile Organic Chemicals, Chelsea, Michigan, Lewis Publishers.

Martin, J. P., Peterson, L. N., and C. J. Taylor, 1999, Field Sampling Plan for the Distler Brickyard Superfund Site, Hardin County, Kentucky, INEEL/EXT-99-00738, August, 1999. 
OHM Corporation, 1990, Basis of Design Report at Distler Brickyard Site, West Point, Kentucky, Unpublished technical report, OHM Project Number J6504, U.S. Environmental Protection Agency Region 4.

USGS, in preparation, Investigation of Trends in Volatile Organic Chemicals in Ground Water at the Former Distler Brickyard Superfund Site, Hardin County, Kentucky, 1995 1997, USGS Water Resources Division Draft Report.

Vogel, T. M., Criddle, C. S., and McCarty, P. L., 1987, "Transformation of halogenated aliphatic compounds," Environmental Science and Technology, Vol. 21, pp. 722-736.

Vogel, T. M. and McCarty, P. L., 1987, "Abiotic and biotic transformations of 1,1,1-trichloroethane under methanogenic conditions," Environmental Science and Technology, Vol. 21, pp. 1208-1213.

Wiedemeier, T. H., et al., 1996, "Natural Attenuation of Chlorinated Aliphatic Hydrocarbons at Plattsburgh Air Force Base, New York," Symposium on Natural Attenuation of Chlorinated Organics in Ground Water, USEPA, EPA/540/R-96/509. 


\section{Appendix A \\ Volatile Organic Analysis Results \\ Total and Dissolved Metals Results}


Results of Volatile Organic Analysis ( $\mu \mathrm{g} / \mathrm{L})$.

\begin{tabular}{|c|c|c|c|c|c|c|c|c|}
\hline Analyte & GW-11 & UDBP-8 & UDBP-7 & MW-1 & MW-2 & MW-3 & UDBP-4 & UDBW-3 \\
\hline Chloromethane & ND & ND & $\mathrm{ND}$ & ND & $\mathrm{ND}$ & $\mathrm{ND}$ & $\mathrm{ND}$ & ND \\
\hline Bromomethane & ND & ND & ND & ND & ND & ND & $\mathrm{ND}$ & ND \\
\hline Vinyl Chloride & ND & $\mathrm{ND}$ & ND & $\mathrm{ND}$ & ND & $\mathrm{ND}$ & ND & ND \\
\hline Chloroethane & 85 & $\mathrm{ND}$ & ND & $\mathrm{ND}$ & $\mathrm{ND}$ & ND & $1 \mathrm{~J}$ & ND \\
\hline Methylene Chloride & ND & $\mathrm{ND}$ & ND & ND & ND & $\mathrm{ND}$ & ND & $\mathrm{ND}$ \\
\hline Acetone & $\mathrm{ND}$ & ND & ND & $\mathrm{ND}$ & ND & ND & ND & $\mathrm{ND}$ \\
\hline Carbon Disulfide & $\mathrm{ND}$ & ND & ND & $\mathrm{ND}$ & ND & $\mathrm{ND}$ & ND & ND \\
\hline 1,1-Dichloroethene & ND & ND & ND & ND & ND & ND & ND & ND \\
\hline 1,1-Dichloroethane & $4 \mathrm{~J}$ & $7 \mathrm{~J}$ & 12 & ND & $1 \mathrm{~J}$ & 26 & 18 & ND \\
\hline Chloroform & ND & $\mathrm{ND}$ & ND & $\mathrm{ND}$ & $\mathrm{ND}$ & $\mathrm{ND}$ & ND & ND \\
\hline 1,2-Dichloroethane & $1 \mathrm{~J}$ & $\mathrm{ND}$ & $2 \mathrm{~J}$ & ND & $\mathrm{ND}$ & $4 \mathrm{~J}$ & $3 \mathrm{~J}$ & $\mathrm{ND}$ \\
\hline Methyl Ethyl Ketone & $\mathrm{ND}$ & $\mathrm{ND}$ & ND & ND & $\mathrm{ND}$ & ND & ND & ND \\
\hline 1,1,1-Trichloroethane & ND & $4 \mathrm{~J}$ & $4 \mathrm{~J}$ & ND & $2 \mathrm{~J}$ & $10 \mathrm{~J}$ & $4 \mathrm{~J}$ & $2 \mathrm{~J}$ \\
\hline Carbon Tetrachloride & $\mathrm{ND}$ & $\mathrm{ND}$ & $\mathrm{ND}$ & ND & $\mathrm{ND}$ & ND & $\mathrm{ND}$ & ND \\
\hline Bromodichloromethane & ND & $\mathrm{ND}$ & ND & ND & $\mathrm{ND}$ & ND & ND & ND \\
\hline 1,2-Dichloropropane & ND & ND & ND & ND & ND & ND & ND & ND \\
\hline c1,3-Dichloropropene & ND & ND & ND & ND & $\mathrm{ND}$ & ND & $\mathrm{ND}$ & $\mathrm{ND}$ \\
\hline Trichloroethene & ND & $9 \mathrm{~J}$ & 11 & ND & $2 \mathrm{~J}$ & $7 \mathrm{~J}$ & $6 \mathrm{~J}$ & ND \\
\hline Dibromochloromethane & ND & ND & ND & ND & ND & $\mathrm{ND}$ & $\mathrm{ND}$ & $\mathrm{ND}$ \\
\hline 1,1,2-Trichloroethane & ND & ND & $1 \mathrm{~J}$ & ND & ND & $1 \mathrm{~J}$ & ND & ND \\
\hline Benzene & $1 \mathrm{~J}$ & ND & $\mathrm{ND}$ & ND & ND & ND & ND & ND \\
\hline t1,3-Dichloropropene & ND & ND & $\mathrm{ND}$ & ND & ND & ND & ND & $\mathrm{ND}$ \\
\hline Bromoform & ND & ND & ND & ND & ND & $\mathrm{ND}$ & ND & ND \\
\hline Methyl Isobutyl Ketone & $\mathrm{ND}$ & ND & ND & $\mathrm{ND}$ & ND & ND & ND & ND \\
\hline Methyl Butyl Ketone & ND & ND & ND & $\mathrm{ND}$ & ND & $\mathrm{ND}$ & ND & ND \\
\hline Tetrachloroethene & ND & ND & ND & ND & ND & ND & ND & ND \\
\hline 1,1,2,2-Tetrachloroethane & $\mathrm{ND}$ & ND & ND & $\mathrm{ND}$ & ND & ND & ND & ND \\
\hline Toluene & ND & ND & ND & $\mathrm{ND}$ & ND & $\mathrm{ND}$ & ND & ND \\
\hline Chlorobenzene & $2 \mathrm{~J}$ & ND & $\mathrm{ND}$ & ND & ND & $\mathrm{ND}$ & ND & ND \\
\hline Ethylbenzene & 270 & ND & $\mathrm{ND}$ & ND & ND & ND & ND & ND \\
\hline Styrene & ND & $\mathrm{ND}$ & ND & ND & ND & ND & ND & ND \\
\hline Total Xylenes & 510 & ND & ND & ND & ND & ND & ND & ND \\
\hline Dichlorodifluoromethane & ND & ND & ND & ND & ND & ND & ND & ND \\
\hline
\end{tabular}


Results of Volatile Organic Analysis $(\mu \mathrm{g} / \mathrm{L})$ (continued).

\begin{tabular}{|c|c|c|c|c|c|c|c|c|}
\hline Analyte & GW-11 & UDBP-8 & UDBP-7 & MW-1 & MW-2 & MW-3 & UDBP-4 & UDBW-3 \\
\hline Trichlorofluoromethane & ND & ND & ND & ND & $\mathrm{ND}$ & ND & ND & ND \\
\hline Methyl Acetate & ND & ND & ND & ND & $\mathrm{ND}$ & ND & ND & $\mathrm{ND}$ \\
\hline t1,2-Dichloroethene & $6 \mathrm{~J}$ & ND & ND & ND & ND & $2 \mathrm{~J}$ & $2 \mathrm{~J}$ & $\mathrm{ND}$ \\
\hline Methyl T-Butyl Ether & $\mathrm{ND}$ & ND & ND & ND & $\mathrm{ND}$ & ND & ND & ND \\
\hline c1,2-Dichloroethene & $\mathrm{ND}$ & 12 & 35 & ND & $3 \mathrm{~J}$ & 65 & 50 & ND \\
\hline Cyclohexane & $1 \mathrm{~J}$ & ND & ND & $\mathrm{ND}$ & $\mathrm{ND}$ & ND & ND & ND \\
\hline Methylcyclohexane & $3 \mathrm{~J}$ & $\mathrm{ND}$ & ND & ND & ND & ND & ND & ND \\
\hline 1,2-Dibromoethane & ND & $\mathrm{ND}$ & $\mathrm{ND}$ & $\mathrm{ND}$ & $\mathrm{ND}$ & ND & ND & $\mathrm{ND}$ \\
\hline Isopropylbenzene & 40 & ND & ND & ND & ND & ND & ND & ND \\
\hline $\begin{array}{l}\text { 1,2-Dibromo-3-Chloropropane } \\
\text { (DBCP) }\end{array}$ & $\mathrm{ND}$ & ND & $\mathrm{ND}$ & ND & ND & ND & ND & ND \\
\hline 1,3-Dichlorobenzene & ND & ND & $\mathrm{ND}$ & ND & ND & ND & ND & $\mathrm{ND}$ \\
\hline 1,4-Dichlorobenzene & ND & $\mathrm{ND}$ & ND & $\mathrm{ND}$ & ND & ND & $\mathrm{ND}$ & $\mathrm{ND}$ \\
\hline 1,2-Dichlorobenzene & $1 \mathrm{~J}$ & ND & ND & ND & ND & ND & ND & ND \\
\hline 1,2,4-Trichlorobenzene & ND & ND & ND & $\mathrm{ND}$ & ND & ND & ND & ND \\
\hline 1-Methyl-Naphthalene & $\mathrm{ND}$ & ND & $7 \mathrm{NJ}$ & $6 \mathrm{NJ}$ & $\mathrm{ND}$ & ND & ND & $\mathrm{ND}$ \\
\hline Benzo(c)Thiophene & ND & ND & $6 \mathrm{NJ}$ & ND & ND & ND & ND & ND \\
\hline Propylbenzene & $56 \mathrm{JN}$ & $\mathrm{ND}$ & ND & $\mathrm{ND}$ & ND & $\mathrm{ND}$ & ND & $\mathrm{ND}$ \\
\hline 1-ethyl-2-methyl-benzene & $85 \mathrm{JN}$ & ND & ND & ND & ND & ND & ND & ND \\
\hline 1,3,5-trimethylbenzene & 69JN & $\mathrm{ND}$ & ND & ND & ND & ND & ND & ND \\
\hline 1-ethyl-4-methyl-benzene & $170 \mathrm{JN}$ & ND & ND & ND & ND & ND & ND & ND \\
\hline 1,2,4-trimethylbenzene & $390 \mathrm{JN}$ & $\mathrm{ND}$ & ND & ND & ND & ND & ND & ND \\
\hline 1,2,3-trimethylbenzene & $120 \mathrm{~N}$ & ND & ND & ND & $\mathrm{ND}$ & ND & ND & ND \\
\hline Freon 113 & ND & $\mathrm{ND}$ & ND & $\mathrm{ND}$ & ND & ND & ND & $2 \mathrm{~J}$ \\
\hline \multicolumn{9}{|l|}{$\begin{array}{l}N=\text { presumptive detection } \\
N D=\text { not detected } \\
A=\text { average value } \\
\mathrm{J}=\text { estimated value }\end{array}$} \\
\hline
\end{tabular}


Total Metals $(\mu \mathrm{g} / \mathrm{L})$.

\begin{tabular}{|c|c|c|c|c|c|c|c|c|}
\hline Analyte & GW-11 & UDBP-8 & UDBP-7 & MW-1 & MW-2 & MW-3 & UDBP-4 & UDBW-3 \\
\hline Aluminum & $\mathrm{ND}$ & ND & ND & ND & ND & ND & $\mathrm{ND}$ & 1500 \\
\hline Antimony & ND & ND & $\mathrm{ND}$ & $\mathrm{ND}$ & ND & ND & ND & ND \\
\hline Arsenic & 100 & 33 & $\mathrm{ND}$ & $\mathrm{ND}$ & ND & ND & $\mathrm{ND}$ & 6.5 \\
\hline Barium & 73 & 160 & 120 & 43 & 63 & 66 & 39 & 140 \\
\hline Beryllium & ND & ND & $\mathrm{ND}$ & ND & $\mathrm{ND}$ & $\mathrm{ND}$ & $\mathrm{ND}$ & $\mathrm{ND}$ \\
\hline Cadmium & $\mathrm{ND}$ & ND & $\mathrm{ND}$ & ND & $\mathrm{ND}$ & $\mathrm{ND}$ & $\mathrm{ND}$ & $\mathrm{ND}$ \\
\hline Calcium & 56000 & 130000 & 110000 & 100000 & 94000 & 130000 & 100000 & 130000 \\
\hline Chromium & ND & $1.4 \mathrm{~J}$ & $\mathrm{ND}$ & ND & $\mathrm{ND}$ & $20 \mathrm{~J}$ & $\mathrm{ND}$ & 310 \\
\hline Cobalt & 8.3 & ND & ND & ND & ND & $\mathrm{ND}$ & ND & 26 \\
\hline Copper & $\mathrm{ND}$ & 6.3 & $\mathrm{ND}$ & $\mathrm{ND}$ & $\mathrm{ND}$ & 4 & $\mathrm{ND}$ & 37 \\
\hline Iron & 2500 & $7500 \mathrm{~J}$ & ND & $\mathrm{ND}$ & $\mathrm{ND}$ & $1000 \mathrm{~J}$ & $25 \mathrm{~J}$ & 13000 \\
\hline Lead & ND & ND & ND & $\mathrm{ND}$ & $\mathrm{ND}$ & $\mathrm{ND}$ & $\mathrm{ND}$ & 8 \\
\hline Magnesium & 54000 & 50000 & 40000 & 34000 & 35000 & 43000 & 31000 & 52000 \\
\hline Manganese & 260 & 570 & 910 & ND & $\mathrm{ND}$ & 72 & $\mathrm{ND}$ & 1300 \\
\hline Mercury & $\mathrm{ND}$ & ND & $\mathrm{ND}$ & $\mathrm{ND}$ & ND & ND & ND & ND \\
\hline Nickel & 34 & 2.9 & 6 & 7.6 & 30 & 21 & $\mathrm{ND}$ & 510 \\
\hline Potassium & $330 \mathrm{~J}$ & $1200 \mathrm{~J}$ & $790 \mathrm{~J}$ & $550 \mathrm{~J}$ & $690 \mathrm{~J}$ & $840 \mathrm{~J}$ & $530 \mathrm{~J}$ & $1500 \mathrm{~J}$ \\
\hline Selenium & $\mathrm{ND}$ & $\mathrm{ND}$ & $\mathrm{ND}$ & $\mathrm{ND}$ & $\mathrm{ND}$ & $\mathrm{ND}$ & $\mathrm{ND}$ & 2.4 \\
\hline Silver & ND & ND & ND & ND & ND & ND & ND & $\mathrm{ND}$ \\
\hline Sodium & 8300 & 97000 & 71000 & 15000 & 17000 & 56000 & 24000 & 32000 \\
\hline Thallium & $\mathrm{ND}$ & ND & ND & $\mathrm{ND}$ & $\mathrm{ND}$ & ND & $\mathrm{ND}$ & $\mathrm{ND}$ \\
\hline Vanadium & ND & ND & ND & ND & $\mathrm{ND}$ & ND & ND & 6.8 \\
\hline Zinc & ND & $\mathrm{ND}$ & $\mathrm{ND}$ & ND & $\mathrm{ND}$ & ND & $\mathrm{ND}$ & 23 \\
\hline Cyanide & ND & ND & $\mathrm{ND}$ & ND & ND & ND & ND & ND \\
\hline $\begin{array}{l}N=\text { presump } \\
N D=\text { not de } \\
A=\text { average } \\
J=\text { estimate }\end{array}$ & & & & & & & & \\
\hline
\end{tabular}


Dissolved Metals $(\mu \mathrm{g} / \mathrm{L})$.

\begin{tabular}{|c|c|c|c|c|c|c|c|c|}
\hline Analyte & GW-11 & UDBP-8 & UDBP-7 & MW-3 & MW-1 & MW-2 & UDBP-4 & UDBW-3 \\
\hline Aluminum & ND & ND & ND & $\mathrm{ND}$ & ND & ND & ND & ND \\
\hline Antimony & ND & ND & ND & ND & ND & ND & $\mathrm{ND}$ & $\mathrm{ND}$ \\
\hline Arsenic & 100 & 30 & 4 & ND & $\mathrm{ND}$ & $\mathrm{ND}$ & ND & ND \\
\hline Barium & 73 & 140 & 120 & 56 & 44 & 63 & 39 & 36 \\
\hline Beryllium & $\mathrm{ND}$ & ND & $\mathrm{ND}$ & ND & $\mathrm{ND}$ & $\mathrm{ND}$ & $\mathrm{ND}$ & ND \\
\hline Cadmium & $\mathrm{ND}$ & $\mathrm{ND}$ & ND & ND & ND & ND & ND & ND \\
\hline Calcium & 56000 & 120000 & 110000 & 120000 & 100000 & 94000 & 100000 & 100000 \\
\hline Chromium & & ND & ND & ND & $26 \mathrm{~J}$ & ND & ND & ND \\
\hline Cobalt & 8.3 & ND & ND & $\mathrm{ND}$ & $\mathrm{ND}$ & ND & ND & ND \\
\hline Copper & ND & $\mathrm{ND}$ & ND & ND & 2 & ND & ND & ND \\
\hline Iron & 2500 & $6200 \mathrm{~J}$ & $1100 \mathrm{~J}$ & ND & $610 \mathrm{~J}$ & $\mathrm{ND}$ & $25 \mathrm{~J}$ & $\mathrm{ND}$ \\
\hline Lead & ND & ND & ND & $\mathrm{ND}$ & ND & ND & ND & $\mathrm{ND}$ \\
\hline Magnesium & 54000 & 46000 & 40000 & 42000 & 34000 & 35000 & 31000 & 40000 \\
\hline Manganese & 260 & 500 & 880 & 7 & 7.8 & $\mathrm{ND}$ & $\mathrm{ND}$ & 8.8 \\
\hline Mercury & ND & ND & ND & ND & ND & ND & $\mathrm{ND}$ & ND \\
\hline Nickel & 34 & & 5.4 & 14 & 19 & 30 & & 44 \\
\hline Potassium & $330 \mathrm{~J}$ & $1000 \mathrm{~J}$ & $780 \mathrm{~J}$ & $740 \mathrm{~J}$ & $590 \mathrm{~J}$ & $690 \mathrm{~J}$ & $530 \mathrm{~J}$ & $1100 \mathrm{~J}$ \\
\hline Selenium & ND & ND & ND & ND & $\mathrm{ND}$ & ND & $\mathrm{ND}$ & 4 \\
\hline Silver & $\mathrm{ND}$ & ND & $\mathrm{ND}$ & ND & $\mathrm{ND}$ & ND & ND & ND \\
\hline Sodium & 8300 & 89000 & 71000 & 55000 & 14000 & 17000 & 24000 & 31000 \\
\hline Thallium & ND & ND & ND & ND & ND & ND & ND & ND \\
\hline Vanadium & ND & ND & ND & ND & ND & ND & ND & ND \\
\hline Zinc & ND & ND & $\mathrm{ND}$ & ND & ND & ND & ND & ND \\
\hline Cyanide & $\mathrm{ND}$ & ND & ND & ND & ND & ND & ND & ND \\
\hline \multicolumn{9}{|c|}{$\begin{array}{l}N=\text { presumptive detection } \\
N D=\text { not detected } \\
A=\text { average value } \\
J=\text { estimated value. }\end{array}$} \\
\hline
\end{tabular}

